\title{
RESEARCH
}

Open Access

\section{Repurposing beta-3 adrenergic receptor agonists for Alzheimer's disease: beneficial effects in a mouse model}

\author{
Marine Tournissac ${ }^{1,2}$, Tra-My Vu ${ }^{1,2}$, Nika Vrabic ${ }^{2}$, Clara Hozer ${ }^{3}$, Cyntia Tremblay², Koralie Mélançon ${ }^{1,2}$, \\ Emmanuel Planel ${ }^{2,4}$, Fabien Pifferi ${ }^{3}$ and Frédéric Calon ${ }^{1,2^{*}}$ (D)
}

\begin{abstract}
Background: Old age, the most important risk factor for Alzheimer's disease (AD), is associated with thermoregulatory deficits. Brown adipose tissue (BAT) is the main thermogenic driver in mammals and its stimulation, through $\beta 3$ adrenergic receptor ( $\beta 3 A R$ ) agonists or cold acclimation, counteracts metabolic deficits in rodents and humans. Studies in animal models show that AD neuropathology leads to thermoregulatory deficits, and cold-induced tau hyperphosphorylation is prevented by BAT stimulation through cold acclimation. Since metabolic disorders and AD share strong pathogenic links, we hypothesized that BAT stimulation through a $\beta 3 A R$ agonist could exert benefits in $A D$ as well.
\end{abstract}

Methods: CL-316,243, a specific $\beta 3 A R$ agonist, was administered to the triple transgenic mouse model of AD (3xTg$A D)$ and non-transgenic controls from 15 to 16 months of age at a dose of $1 \mathrm{mg} / \mathrm{kg} /$ day i.p.

Results: Here, we show that $\beta 3 A R$ agonist administration decreased body weight and improved peripheral glucose metabolism and BAT thermogenesis in both non-transgenic and 3xTg-AD mice. One-month treatment with a $33 A R$ agonist increased recognition index by 19\% in 16-month-old 3xTg-AD mice compared to pre-treatment (14-monthold). Locomotion, anxiety, and tau pathology were not modified. Finally, insoluble $A \beta 42 / A \beta 40$ ratio was decreased by $27 \%$ in the hippocampus of CL-316,243-injected 3xTg-AD mice.

Conclusions: Overall, our results indicate that $\beta 3 A R$ stimulation reverses memory deficits and shifts downward the insoluble $A \beta 42 / A \beta 40$ ratio in 16-month-old 3xTg-AD mice. As $\beta 3 A R$ agonists are being clinically developed for metabolic disorders, repurposing them in $A D$ could be a valuable therapeutic strategy.

Keywords: Alzheimer's disease, $\beta 3$ adrenergic receptors, Drug repurposing, Thermogenesis, 3xTg-AD mice, Brown adipose tissue

\footnotetext{
* Correspondence: frederic.calon@crchul.ulaval.ca

${ }^{1}$ Faculté de pharmacie, Université Laval, 1050 Avenue de la Médecine, Quebec, QC G1V 0A6, Canada

${ }^{2}$ Axe Neurosciences, Centre de recherche du CHU de Québec-Université Laval (Pavillon CHUL), 2705 Boulevard Laurier, Quebec, QC G1V 4G2, Canada Full list of author information is available at the end of the article
}

C The Author(s). 2021 Open Access This article is licensed under a Creative Commons Attribution 4.0 International License, which permits use, sharing, adaptation, distribution and reproduction in any medium or format, as long as you give appropriate credit to the original author(s) and the source, provide a link to the Creative Commons licence, and indicate if changes were made. The images or other third party material in this article are included in the article's Creative Commons licence, unless indicated otherwise in a credit line to the material. If material is not included in the article's Creative Commons licence and your intended use is not permitted by statutory regulation or exceeds the permitted use, you will need to obtain permission directly from the copyright holder. To view a copy of this licence, visit http://creativecommons.org/licenses/by/4.0/. The Creative Commons Public Domain Dedication waiver (http://creativecommons.org/publicdomain/zero/1.0/) applies to the data made available in this article, unless otherwise stated in a credit line to the data. 


\section{Background}

Old age is the main risk factor of Alzheimer's disease (AD), a neurodegenerative disorder clinically expressed by memory deficits and cognitive dysfunction $[1,2]$. The prevalence of $\mathrm{AD}$ is growing fast along with the aging population [3]. Yet, the exact pathogenic causes of the sporadic form of the disease are unknown. Despite decades of intense research and clinical trials, there is still no curative treatment for AD. Since AD is a complex and multifactorial disease, with frequent age-related comorbidities, multi-target agents might be advantageous over a single-bullet approach. The undeniable impact of old age on $\mathrm{AD}$ incidence indicates that aging triggers etiopathological factors of $\mathrm{AD}$; identifying these key factors could provide invaluable clues to the development of novel therapeutic treatments.

Deficits in thermoregulation are among the documented consequences of old age. Although few studies investigated thermoregulation in $\mathrm{AD}$ individuals, it is well known that thermoregulatory defects appear in the elderly, the population primarily affected by AD [4-7]. Mounting evidence now supports the hypothesis that thermoregulation deficits contribute to the development of AD pathology. Spontaneous thermoregulation deficits occur in mouse models of AD neuropathology, including the triple transgenic (3xTg-AD) mice [8-11]. Studies in mouse and hibernators repeatedly showed that decreased body temperature leads to increased tau phosphorylation [12-14]. Supporting the link with age, cold-induced tau phosphorylation is potentiated in old mice compared to young mice [15]. Accordingly, acute manipulation of body temperature leads to strong modulation of $\mathrm{AD}$ neuropathology in mice: hypothermia induced by cold exposure increases both tau phosphorylation and amyloid- $\beta(A \beta)$ pathology and decreases synaptic proteins, while restoring normothermia by exposure to higher room temperature reverses memory and anxiety-like behavior and reduced $A \beta 42$ peptide levels in 3xTg-AD mice [9]. More recently, our group provided evidence that sustained enhancement of thermogenesis through cold acclimation improves metabolic disorders and protects old 3xTg-AD mice from cold-induced tau phosphorylation [16]. Altogether, these observations suggest that thermoregulatory mechanisms could be a potential therapeutic target in AD.

Beside thermoregulation, metabolic diseases share strong pathogenic links with AD. Indeed, induction of a diabetic phenotype such as glucose intolerance has been repeatedly shown to increase $A D$ neuropathology in a mouse model of AD [17-20]. Central insulin signaling defects and lower brain glucose metabolism are observed in $\mathrm{AD}[21,22]$. It is estimated that one out of ten cases of $\mathrm{AD}$ is attributable to type 2 diabetes (T2D) [23]. These observations logically led to the idea of repurposing T2D drugs in $\mathrm{AD}$ [24]. Insulin, thiazolidinediones and glucagon-like peptide- 1 analog are still the subject of clinical trials in dementia, albeit with mitigated results [25-27]. Thus, common metabolic targets between both diseases such as thermoregulatory defects are of interest to develop new therapeutic tools in AD.

Brown adipose tissue (BAT) is an essential thermogenic driver in mammals [28]. The discovery of functional BAT in adults in 2009 has revived research on this tissue $[29,30]$. The ability of BAT thermogenesis to improve main metabolic disorders is now wellestablished in young [31-33] and old mice [16]. Pharmacological tools have been developed in this direction. In particular, $\beta 3$ adrenergic receptor ( $\beta 3 \mathrm{AR})$ agonists are being extensively used to stimulate $\beta 3 A R$ located on brown adipocytes, thereby leading to lipolysis and uncoupling protein 1 (UCP1) expression, the main marker of non-shivering thermogenesis [34, 35]. CL-316,243 is a highly specific B3AR agonist frequently used in metabolic studies in rodents. It has been shown to improve blood glucose metabolism, insulin sensitivity, and energy expenditure and to regulate lipids metabolism [36-40]. Since $\beta 3 A R$ agonists can correct metabolic disorders by enhancing BAT activity, they could tackle both T2D and $\mathrm{AD}$ at the same time. Importantly, $\beta 3 \mathrm{AR}$ agonists have been shown to stimulate BAT activity in humans [41, 42], and one of these molecules, mirabegron (Myrbetriq ${ }^{\circ}$ ), is now approved for the treatment of overactive bladder [43]. Therefore, ß3AR agonists could rapidly be tested in humans for dementia.

We hypothesized that pharmacological stimulation of BAT thermogenesis through B3AR agonist treatment could curtail AD neuropathology and improve memory as well as correcting thermoregulatory and metabolic deficits. To verify this hypothesis, 15month-old non-transgenic (NonTg) and 3xTg-AD mice received daily CL-316,243 $(1 \mathrm{mg} / \mathrm{kg})$ or saline injections for a month.

\section{Methods \\ Animals}

The triple transgenic mouse model of AD (homozygous 3xTg-AD; $\mathrm{APP}_{\mathrm{swe}}, \mathrm{PS}_{\mathrm{M} 146 \mathrm{~V}}$, tau $\mathrm{P}_{\mathrm{P} 31 \mathrm{~L}}$ ) developing both amyloid and tau pathologies in the brain with age was used here [44], and compared to a NonTg control mouse on the same genetic background (C57BL6/ 129Svj). We selected 15-month-old 3xTg-AD and NonTg controls, at an age when 3xTg-AD mice have extended plaques and tangles in the brain, as well as cognitive deficits [45-48]. Animals were produced at our animal facility and all maintained in the same genetic background (C57BL6/129SvJ) by backcrossing every 8 10 generations. Forty-two (42) mice were used for all experiments $(n=9-12$ mice per group) and 9 mice were 
added for behavioral and glucose tolerance tests for a total of 51 mice ( $n=9-16$ mice per group).

Mice were housed one to five per cage at a housing temperature of $23.029 \pm 0.098^{\circ} \mathrm{C}$, with a $12: 12$-h lightdark cycle (light phase from 7 a.m. to 7 p.m). Animals had ad libitum access to water and chow (Teklad 2018, Harlan Laboratories, Canada). Only males were used here to avoid temperature variation induced by the estrous cycle of female mice [49]. Food consumption was evaluated by weighing the diet of each cage and averaged for each mouse per day per cage every 4 days during the 1-month treatment, and 3 weeks before the beginning of the experiment. At the end of the experiment, all mice were put under deep anesthesia with ketamine/xylazine intraperitoneal (i.p.) injection $(100 \mathrm{mg} / \mathrm{kg}$ ketamine, 10 $\mathrm{mg} / \mathrm{kg}$ xylazine) and immediately placed under a heating pad to maintain body temperature until complete loss of posterior paw reflex. Then, mice were rapidly sacrificed by intracardiac perfusion with $0.1 \mathrm{M}$ phosphate buffer saline (PBS) solution containing phosphatase (sodium pyrophosphate, $1 \mathrm{mM}$ and sodium fluoride, $50 \mathrm{mM}$ ) and protease (Sigmafast protease inhibitor tablets, SigmaAldrich, St-Louis, USA) inhibitors. All experiments were performed in accordance with the Canadian Council on Animal Care and were approved by the Institutional Committee of the Centre Hospitalier de l'Université Laval (CHUL).

\section{CL-316,243 treatment}

CL-316,243 was selected to stimulate BAT thermogenesis because it is one of the most selective $\beta 3 \mathrm{AR}$ agonists in rodents $(\beta 1: \beta 2: \beta 3=0: 1: 100,000)$ and its safety and efficacy has been confirmed in multiple studies [50-54]. Two to 3 weeks of daily injection at a dose of $1 \mathrm{mg} / \mathrm{kg}$ per day are necessary to improve metabolic disorders [36-40]. Thus, mice were injected i.p. every day for a month (25 consecutive injections) with a weightadjusted dose of CL-316,243 (1 mg/ $\mathrm{kg})$ or an equivalent volume of saline (the vehicle) at the same hour of the day (4 p.m.) from 15 to 16 months of age (Fig. 1a). Mice were weighed every day before each i.p. injection. Mice were sacrificed the morning after the last injection (exactly on the 26th day after the first injection).

\section{Body temperature measurement and analysis}

Telemetric probes (Anipill, Caen, France) were used to record body temperature of the animals every hour during the 1-month experiment without manipulation. Probes were implanted in the intraperitoneal cavity under isoflurane anesthesia a week before the beginning of the treatment to allow recovery from the surgery (Fig. 1a). Heat pads were used throughout the procedure to avoid hypothermia. The time under anesthesia was similar between mice and lasted approximately $10 \mathrm{~min}$.
Then, the animals were kept under heat pads during the waking period. Body temperature was analyzed during the two first weeks of treatment, before animals underwent glucose tolerance and behavioral tests, to avoid resulting interference in circadian rhythms.

In order to assess potential phase advances or delays and to visualize endogenous rhythmicity and regularity of the mice circadian clock, Clocklab software (Actimetrics Inc., Evanston, Illinois, USA) provided the further information: individual mean daily offsets in hours (determined as the time of the first six successive bins when temperature was lower than the mean diurnal temperature), offset standard deviation in hours and mean duration of a total temperature cycle in hours. We performed our analyses based on daily offsets (the end of the active period of the mice) because daily injections of the drug were performed only $3 \mathrm{~h}$ before the lights turned off, thus influencing the onsets (the beginning of the active period). Other following parameters were calculated for each individual: mean body temperature in degrees Celsius during the dark (from 7 p.m. to 7 a.m.) and light phase (from 7 a.m. to 7 p.m.) and mean amplitude of temperature $\left(\mathrm{T}^{\circ} \mathrm{max}-\mathrm{T}^{\circ} \mathrm{min}\right)$ in degrees Celsius during the dark and light phase.

\section{Glucose tolerance test, fasting blood glucose, leptin, insulin, and triglyceride measurement}

Glucose tolerance test (GTT) was performed at the end of the third week of treatment (Fig. 1a) [47]. Mice were fasted for $6 \mathrm{~h}$ (from 8 a.m. to 2 p.m.). Then, glucose was injected i.p. at $1 \mathrm{~g} / \mathrm{kg}$ and blood glucose was measured regularly during $2 \mathrm{~h}$ with a glucometer (OneTouch UltraMini; LifeScan, Milpitas, CA) in a blood drop sampled from the saphenous vein. Leptin and insulin were assessed by ELISAs (Leptin Mouse ELISA kit, ab100718, Abcam; mouse insulin ELISA, \#10-1247-01, Mercodia, Sweden) following the manufacturer's instructions in plasma sampled in the saphenous vein after the 6-h fasting during the GTT test. Triglycerides were measured in blood sampled at the end of the experiment, just before sacrifice, by an enzymatic assay (Infinity Triglycerides Liquid Stable Reagent, Thermo Fisher Scientific, Waltham, MA).

\section{Behavioral tests}

Behavioral tests were performed during the fourth week of treatment with a recovery time of at least $24 \mathrm{~h}$ between tests (Fig. 1a). The novel object recognition (NOR) test was also performed 3 weeks before the beginning of the treatment to obtain a baseline index ratio for each animal (see below). Mice were acclimated overnight to the testing room located next to the housing room. 


\section{A NonTg, 3xTg-AD mice Saline or CL-316,243 treatment $(1 \mathrm{mg} / \mathrm{kg} /$ day i.p.)}

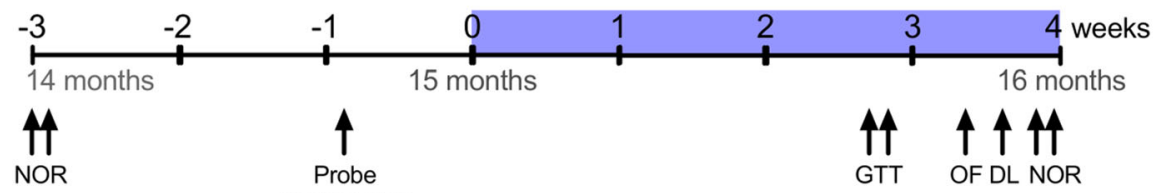

implantation
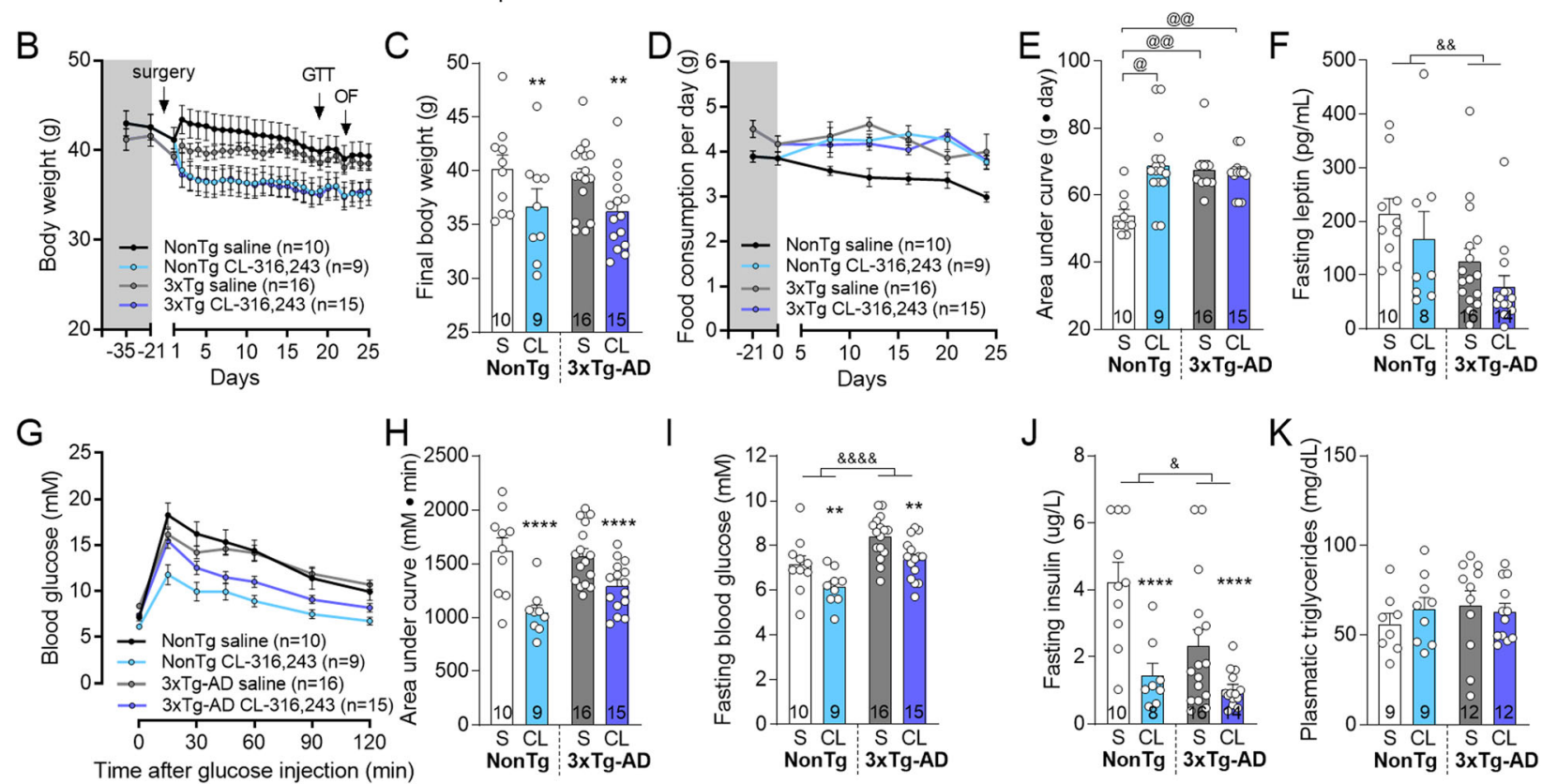

Fig. 1 B 3 AR stimulation improves peripheral glucose metabolism in NonTg and 3xTg-AD mice. a Schematic description of the experimentation. $\mathbf{b}$ Body weight of the mice measured before and during the 1-month experiment (before each i.p. injection) and $\mathbf{c}$ at the end of the experiment. $\mathbf{d}$ Food consumed per day per mice 3 weeks before and over the 1-month treatment and $\mathbf{e}$ area under curve of food consumption over the 1month treatment measured by weighting the diet every 4 days. $\mathbf{f}$ Leptin measured in plasma of fasted mice by ELISA. $\mathbf{g}$ GTT consists in measuring the blood glucose in fasted mice for 6 - $\mathrm{h}$ after a bolus injection of glucose ( $1 \mathrm{~g} / \mathrm{kg}$ i.p.). GT was performed after 3 weeks of experiment and $\mathbf{h}$ area under curve of the GTT. $\mathbf{i}$ Fasting blood glucose and $\mathbf{j}$ plasmatic insulin measured during the GTT with a glucometer or by ELISA, respectively. $\mathbf{i}$ Triglycerides measured in the plasma sampled at the end of the experiment. Data are represented as mean \pm SEM ( $n / g r o u p$ indicated in graphs). Statistics: Two-way ANOVA, effect of treatment: ${ }^{* *} p<0.01$; ${ }^{* * *} p<0.0001$; effect of genotype: ${ }^{\&} p<0.05$; \&\& $p<0.01$; \&\&\&\& $p<$ 0.0001 (c, f, h, i, j). Kruskal-Wallis, Dunn's post hoc test: ${ }^{\circledR} p<0.05 ;{ }^{@}{ }^{0} p<0.01$ (e). Abbreviations: 3xTg-AD: triple transgenic mice; $C L: C L-316,243-$ injected group; DL: dark-light emergence test; GTT: glucose tolerance test; NonTg: non-transgenic mice; NOR: novel object recognition test; OF: open field; S: saline-injected group

Locomotor activity was assessed with the open field test [55]. Mice were placed in a $40 \mathrm{~cm} \times 40 \mathrm{~cm} \times 40 \mathrm{~cm}$ translucent Plexiglas box for an hour. Movements were tracked with photobeam breaks (San Diego Instruments). The total distance traveled (voluntary horizontal movement) and the average speed were compared between groups.

Anxiety behavior was evaluated with the dark-light emergence test [9]. Mice were put in the center of the dark compartment with an opening to the light compartment. The time spent in the light compartment and the latency to do the first exploration (nose latency) of the light compartment were measured during a 5-min trial.

Memory deficits were evaluated with the NOR test. That test detects behavioral deficits from 12 months in $3 \times \mathrm{Tg}-\mathrm{AD}$ mice and is one of the less stressful behavioral test $[9,46,56,57]$. It evaluates recognition memory and corresponds to episodic memory that is early affected in $\mathrm{AD}$ [58-60]. Mice were first placed in a $29.2 \mathrm{~cm} \times 19 \mathrm{~cm}$ $\times 12.7 \mathrm{~cm}$ cage with two identical objects for 5 min during the acquisition phase. After an hour in their housing cage, mice returned in the testing cage containing a familiar and a novel object for the test phase. Recognition index (RI) corresponds to the time spent exploring the novel object divided by the total time of exploration during the test phase multiplied by 100 . A $50 \%$ RI corresponds to an equal exploration between the novel and the familiar object. Mice exploring less than $6 \mathrm{~s}$ each object during the acquisition phase or less than $4 \mathrm{~s}$ during the test phase were excluded from the RI analysis. Mice were assigned to the treated or the control group at 15 months of age with caution to homogenize memory 
performance (baseline RI) between groups at the beginning of the experiment.

\section{Tissue preparation for postmortem analysis}

Intracardiac blood sampled just before intracardiac perfusion in a heparinized tub was centrifuged at $3000 \mathrm{rpm}$ for $5 \mathrm{~min}$, and resulting plasma kept frozen at $-80^{\circ} \mathrm{C}$ until analysis. The first hemisphere and interscapular BAT were rapidly dissected and frozen at $-80^{\circ} \mathrm{C}$ until processing. The second hemisphere was either fixed in $4 \%$ paraformaldehyde for $48 \mathrm{~h}$ and transferred in a $20 \%$ sucrose solution until sectioning (3-4 mice per group) or frozen and kept at $-80^{\circ} \mathrm{C}$.

\section{Protein extractions}

For the hippocampus, frozen samples were homogenized in 8 volumes of a lysis buffer $(150 \mathrm{mM} \mathrm{NaCl}, 10 \mathrm{mM}$ $\mathrm{NaH}_{2} \mathrm{PO}_{4}, 0.5 \%$ sodium deoxycholate, $0.5 \%$ sodium dodecyl sulfate, $1 \%$ Triton X-100) containing a cocktail of protease and phosphatase inhibitors (Bimake, Houston, TX), sonicated ( $3 \times 45 \mathrm{~s}$ in a Sonic Dismembrator apparatus, Thermo Fisher Scientific, Waltham, MA) and centrifuged $\left(100,000 \mathrm{~g}, 20 \mathrm{~min}, 4^{\circ} \mathrm{C}\right)$, resulting in a detergent-soluble fraction (cytosolic, extracellular, and membrane-bound proteins). The remaining pellets from ultracentrifugation were resuspended in formic acid, resulting in a detergent-insoluble fraction (insoluble proteins fraction). The resultant suspension was sonicated and centrifuged $\left(13,000 \mathrm{~g}, 20 \mathrm{~min}, 4^{\circ} \mathrm{C}\right)$, acid formic was evaporated and proteins were either solubilized in Laemmli's buffer for Western blot or in a $5 \mathrm{M}$ guanidium solution in Tris- $\mathrm{HCl} 50 \mathrm{mM}$ for $\mathrm{A} \beta$ peptide ELIS As as previously described [61]. Proteins from the BAT were extracted in the lysis buffer only. Protein concentrations were evaluated with a bicinchoninic acid assay (BCA, Pierce, Rockford, IL, USA).

\section{Western immunoblotting}

In total, $15 \mu \mathrm{g}$ and $10 \mu \mathrm{g}$ of proteins of hippocampus and BAT homogenates, respectively, were loaded and separated by SDS-PAGE, as previously described [17]. The list of antibodies used in this study is available in Additional File 3. Homogenates were all run on the same gel for each experiment. Membranes were imaged using the myECL imager system (Thermo Fisher Scientific). Quantifications were performed using the ImageLab software (Millipore), and the results were expressed as relative optical densities (OD). For the analysis of the protein tau, bands from all isoforms detected around $60 \mathrm{kDa}$ were selected and quantified together.

\section{$A \beta 40$ and $A \beta 42$ peptides quantification}

$A \beta$ peptides were quantified in protein extracts from the hippocampus. $A \beta 40$ and $A \beta 42$ were measured in detergent-soluble and detergent-insoluble fractions using a human amyloid- $\beta$ ELISA (Wako, Osaka, Japan) according to the manufacturer's instructions. Plates were read at $450 \mathrm{~nm}$ using a Synergy ${ }^{\mathrm{TM}}$ HT multi-detection microplate reader (Biotek, Winooski, VT).

\section{High-performance liquid chromatography (HPLC)}

HPLC was used to measure the level of norepinephrine in BAT. An average of $10 \mathrm{mg}$ of BAT was homogenized in perchloric acid $(0.1 \mathrm{~N})$ and centrifuged $10 \mathrm{~min}$ at $4{ }^{\circ} \mathrm{C}$ at $13,000 \mathrm{rpm}$. Five microliters of the supernatant was injected in the HPLC with electrochemical detection (Water 717 plus Autosampler automatic injector, Waters 1525 Binary Pump) as previously described [62].

\section{Statistical analysis}

Data are represented as means \pm standard error of the mean (SEM). Statistical analysis and the number of samples per group are specified in each figure and legend. Bartlett's tests were used to rule out the inequality of variances between the groups. Two-way ANOVA (two independent variables: genotype and treatment) was used in case of equal variances. Repeated measures twoway ANOVA was executed to compare recurrent measurements in same animals. Tukey's test was used for post hoc analysis. In case of unequal variances, a Kruskal-Wallis followed by a Dunn's post hoc test was performed. An unpaired Student's $t$ test was performed when only two groups were compared, with a Welch correction in case of unequal variances. Paired $t$ test was executed for the before-and-after on comparison on the same animals. One sample $t$ test was used to compare means to a theoretical value (for the NOR test). Correlations between variables were investigated using linear regression analyses. A Grubb's test was performed to test for outliers. All statistical analyses were performed with Prism 7 (GraphPad Software Inc., San Diego, CA, USA) or JMP (version 13.2.0; SAS Institute Inc., Cary, IL, USA) software and statistical significance was set at $p<0.05$.

\section{Results \\ B3AR stimulation improves peripheral glucose metabolism in old mice}

NonTg and 3xTg-AD mice received CL-316,243 or saline i.p. at a dose of $1 \mathrm{mg} / \mathrm{kg}$ every day for a month from 15 to 16 months of age (Fig. 1a). To verify whether CL316,243 affects energy balance, mice were weighed every day before each i.p. injection and food consumption was evaluated 3 weeks before the beginning of the experiment and then every 4 days during the 1-month treatment. First, we found that CL-316,243 injections induced persisting weight loss in both NonTg and 3xTg$\mathrm{AD}$ mice (Fig. 1b, c for AUC statistical comparison). At 


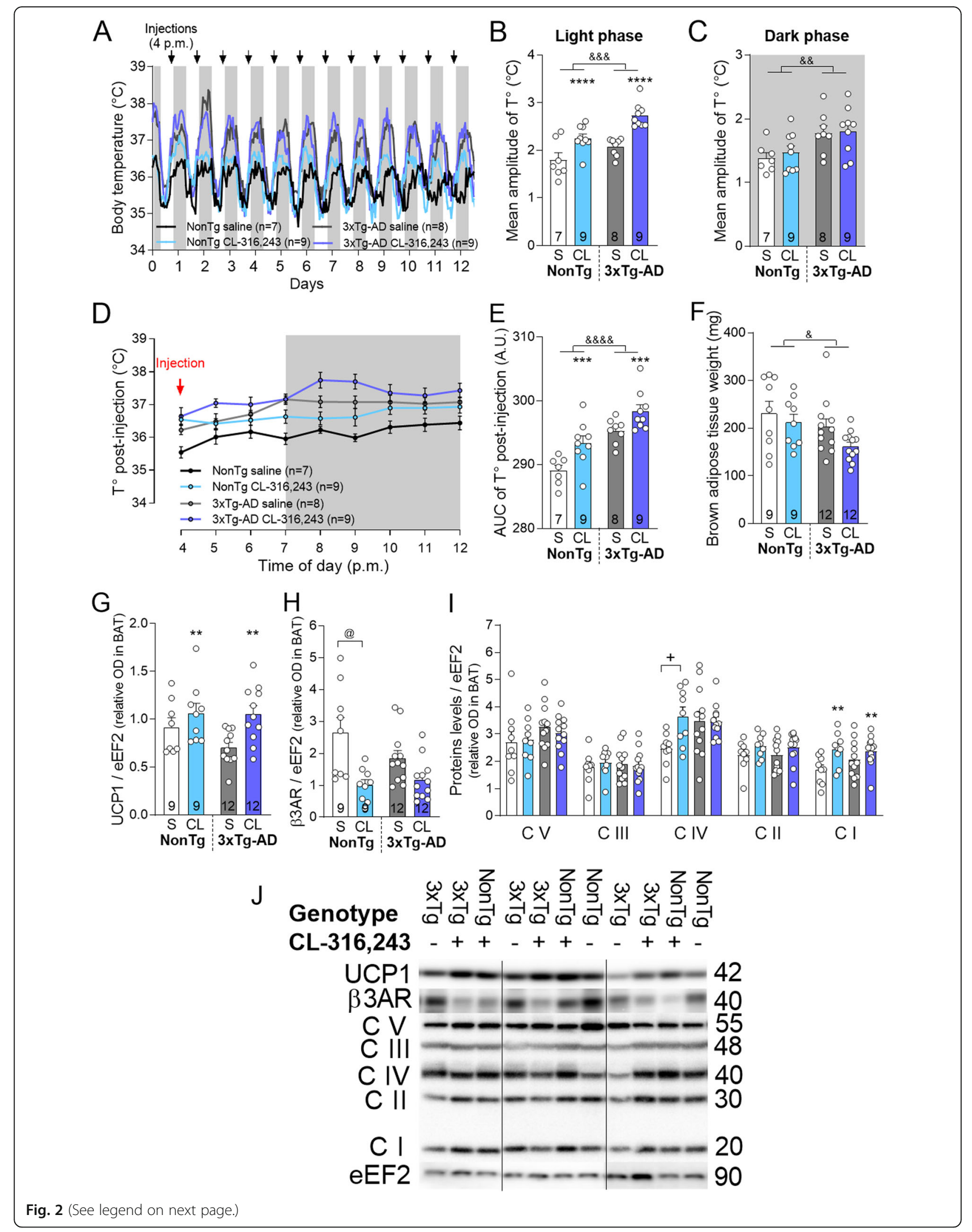




\section{(See figure on previous page.)}

Fig. 2 CL-316,243 treatment increases brown adipose tissue thermogenesis. a Graphical representation of body temperature recorded hourly by telemetric probe implanted in the intraperitoneal cavity during the first 2 weeks of experiment (before glucose tolerance and behavioral tests). Grey rectangles indicate the dark phase and black arrows point toward each i.p. injection of CL-316,243 or saline. b Mean amplitude of body temperature during the light (12-h, from 7 a.m.) and $\mathbf{c}$ the dark phase (12-h, from 7 p.m.). $\mathbf{d}$ Body temperature $\left(\mathrm{T}^{\circ}\right)$ and $\mathbf{e}$ area under curve of the $\mathrm{T}^{\circ}$ after the first CL-316,243 or saline i.p. injection. $\mathbf{f}$ Interscapular BAT weights sampled at sacrifice. Levels of $\mathbf{g}$ UCP1, $\mathbf{h}$ B3AR, and $\mathbf{i}$ mitochondrial oxidative phosphorylation system normalized on eEF2 proteins measured in BAT by Western Blot. $\mathbf{j}$ Examples of Western blots in BAT samples. Homogenates were all run on the same gel, but consecutive bands were not taken for all representative photo examples. Data are represented as mean \pm SEM ( $n$ /group indicated in each column). Statistics: two-way ANOVA, effect of treatment: ${ }^{* *} p<0.01$; ${ }^{* * *} p<0.001 ;{ }^{* * *} p<0.0001$; effect of genotype: ${ }^{\&} p<0.05 ;{ }^{\& \&} p<0.01 ;{ }^{\& \& \&} p<0.001 ;{ }^{\& \& \& \&} p<0.0001$ (b, $\left.\mathbf{c}, \mathbf{e}-\mathbf{g}, \mathbf{i}\right)$; Tukey's post hoc test: ${ }^{+} p<0.05$. Kruskal-Wallis (i), Dunn's post hoc test: ${ }^{@} p<0.05$ (h). Abbreviations: AUC: area under curve; 3xTg-AD: triple transgenic mice; $\beta 3$ AR: $\beta 3$ adrenergic receptor; BAT: brown adipose tissue; CL: CL-316,243-injected group; CV, CIII, CIV, CII, Cl: mitochondrial oxidative phosphorylation system complex V, III, IV, II, l; eEF2: eukaryotic elongation factor 2; NonTg: non-transgenic mice; OD: optical density; S: saline-injected group; $T^{\circ}$ : temperature; UCP1: uncoupling protein 1

the beginning of the experiment, food consumption recorded in the previous 21 days was higher in $3 x T g-A D$ compared to NonTg mice (average of $4.7 \mathrm{~g} /$ day/mice for 3xTg-AD versus $3.9 \mathrm{~g} /$ day $/$ mice for NonTg mice; unpaired $t$-test with Welch's correction: $p=0.0105$ ) (Fig. 1d and e for AUC statistical comparison), consistent with lower plasmatic leptin in fasted 3xTg-AD mice compared to NonTg (Fig. 1f). Over the 1-month period, B3AR stimulation increased food consumption in NonTg mice up to levels of transgenic mice (Fig. 1d, e for AUC statistical comparison). The GTT revealed that CL-316, 243-treated mice displayed a stronger control over glucose levels compared to control, independently of the genotype (Fig. 1g, h for AUC statistical comparison). Fasting blood glucose and insulin were also lower following 3 weeks of CL-316,243 administration (Fig. 1i, j). However, levels of plasmatic triglycerides were unchanged (Fig. 1k). Overall, our data indicate that $\beta 3 \mathrm{AR}$ stimulation led to an improved pattern of metabolic determinants in the periphery in both NonTg and 3xTgAD mice at 15-16 months of age.

\section{$\beta 3$ AR stimulation increases brown adipose tissue thermogenesis}

A telemetric probe implanted a week before the beginning of the treatment revealed daily variation in body temperature corresponding to the sleep-wake cycles of mice (Fig. 2a, Fig. S1). The mean amplitude of body temperature was larger by $0.4{ }^{\circ} \mathrm{C}$ in $3 \mathrm{xTg}$ - AD than in NonTg mice during both 12-h light and 12-h dark phases (Fig. 2a-c, Fig. S1D). CL-316,243 treatment further increased the amplitude of body temperature during the light phase (from 7 a.m. to 7 p.m.) compared to saline injections (Fig. 2b), corresponding to the injection time, but not during the dark phase (Fig. 2c). This is consistent with higher area under curve of body temperature measured after the first injection of CL-316, 243 (between 4 p.m. and 12 p.m.) (Fig. 2d and e for AUC statistical comparison).

Since CL-316,243 is well known to improve thermogenesis capacity in mice $[39,63,64]$, we then verified whether it was also effective in old NonTg and 3xTg-AD mice. First, interscapular BAT weight was slightly lower in 3xTg-AD compared to NonTg mice, but was not affected by the treatment (Fig. 2f). However, CL-316,243 administration increased the level of UCP1 protein in the BAT of both genotypes (Fig. $2 \mathrm{~g}$ ) but did not affect the norepinephrine content (Additional File 1). Further confirming that CL-316,243 interacted with $\beta 3 \mathrm{AR}$, levels of $\beta 3 A R$ in BAT were significantly decreased only in NonTg-treated mice, despite a tendency also in 3xTg$\mathrm{AD}$ mice (Fig. 2h). We then measured complexes I to $\mathrm{V}$ of the mitochondrial oxidative phosphorylation complex that are involved in heat production during thermogenesis in BAT [65]. Complex I was increased in NonTg and 3xTg-AD mice following CL-316,243 administration (Fig. 2i, j). CL-316,243 increased complex IV in NonTg, but not in 3xTg-AD mice, whereas complexes II, III, and $\mathrm{V}$ remained unchanged in both models. Altogether, our data show that the $\beta 3 A R$ agonist administration improves BAT thermogenesis and heat production in 16month-old mice.

B3AR stimulation reverses memory deficits in 16-monthold 3xTg-AD mice

To determine whether CL-316,243 treatment exerted cognitive benefits in the $3 x \mathrm{Tg}-\mathrm{AD}$ mouse, recognition memory was evaluated with the NOR test 3 weeks before the beginning of the treatment (baseline, 14-month-old) and after the 1-month treatment (final, 16-month-old) (Fig. 1a). The NOR test was selected because of its sensitivity and reliability to detect memory deficits in the 3xTg-AD mice at 12 months and older (Fig. 3a) [9, 56, 57]. Comparing RI before ( 14 months) and after (16 months) the treatment revealed that 1-month treatment with CL-316,243 increased by $19 \%$ the ability to recognize the new object in 3xTg-AD mice (paired $t$ test: $p=0.0041$ ), while the change in RI was not significantly different in NonTg or saline-injected 3xTg-AD mice (Fig. 3b, c). CL-316,243 from 15 to 16 months improved memory recognition in 3xTg-AD mice $(\mathrm{RI}=65 \%$ in CL-316,243-injected mice, one sample $t$-test versus 


\section{Novel object recognition}
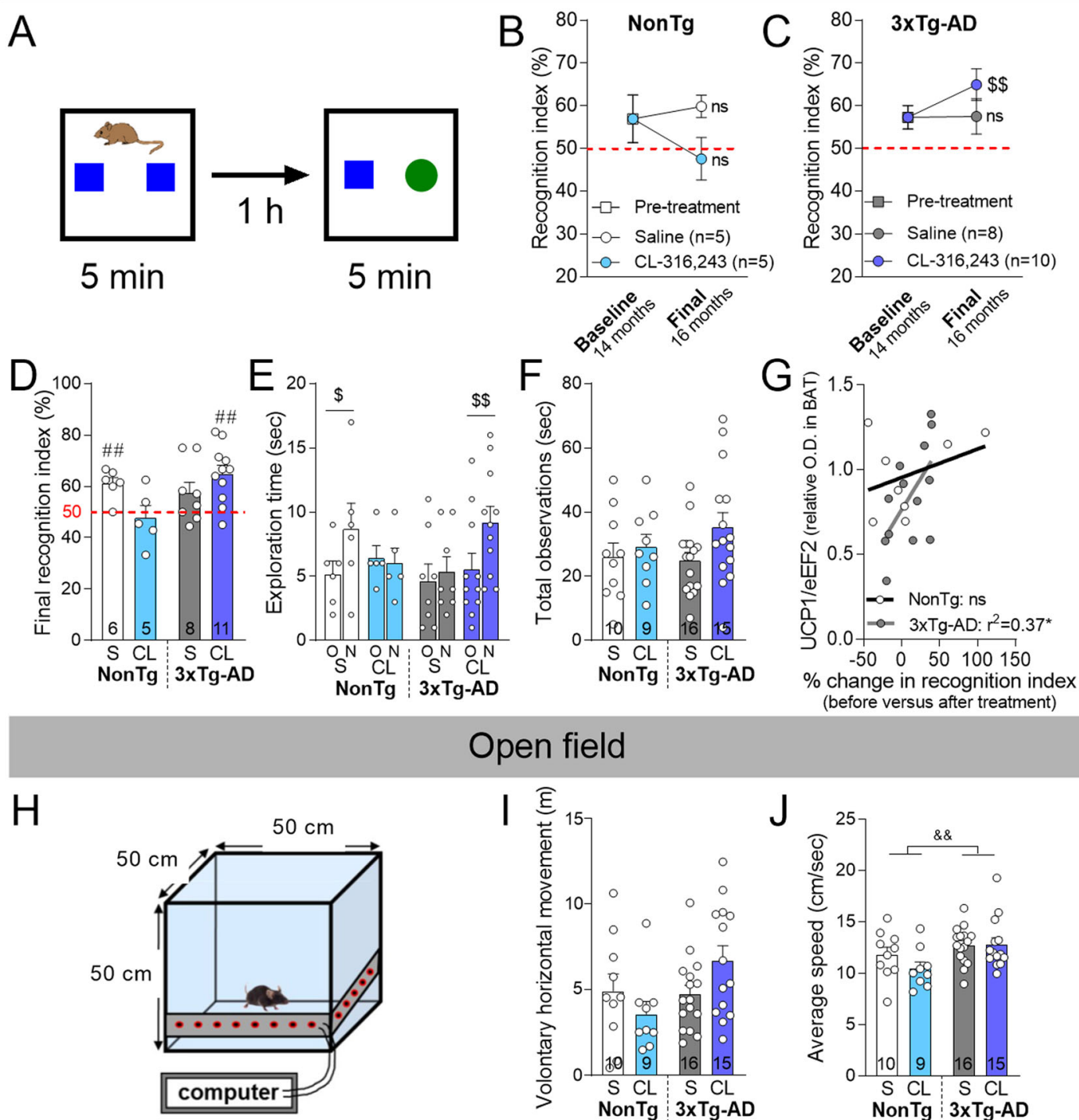

\section{Open field}
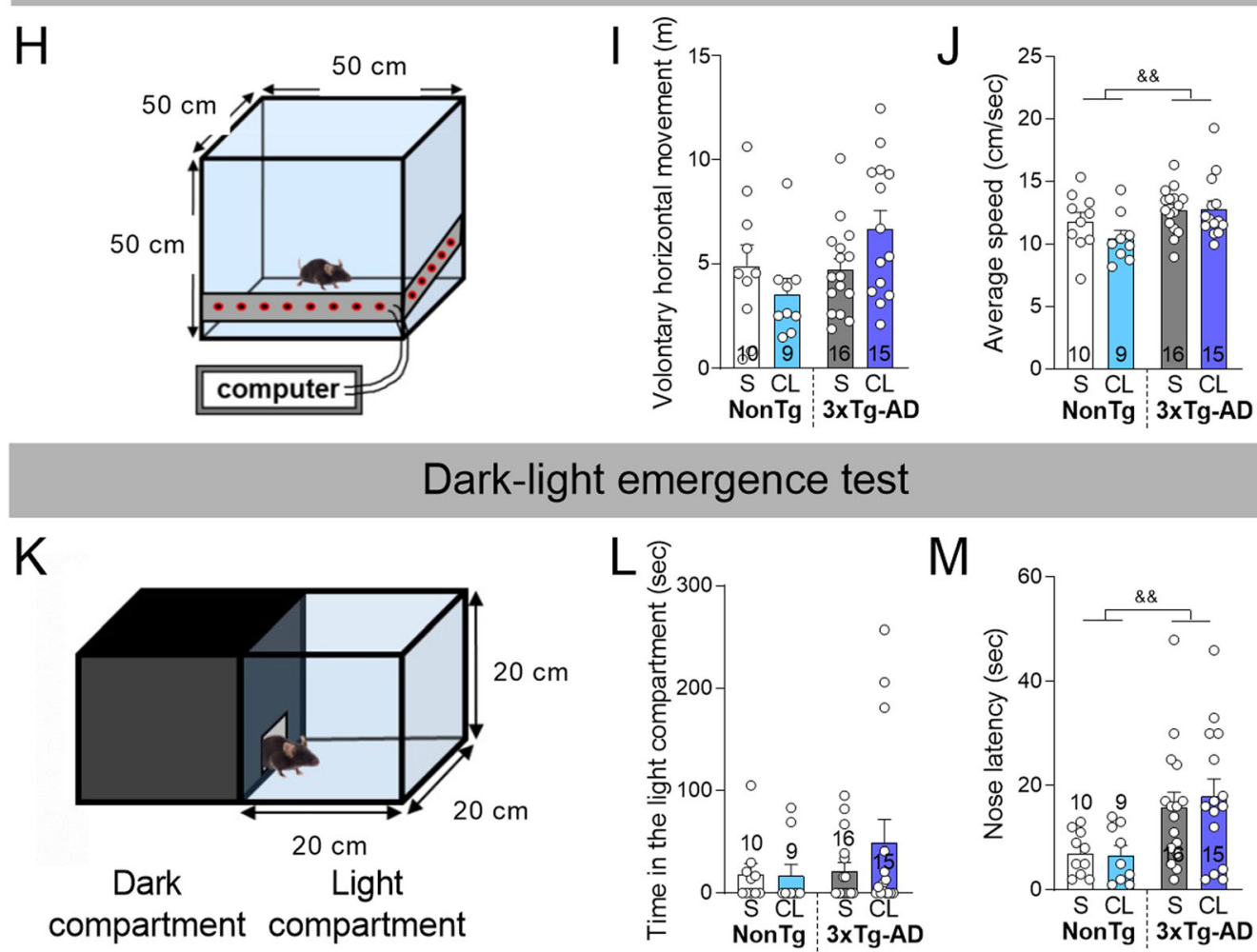

Fig. 3 (See legend on next page.) 
(See figure on previous page.)

Fig. 3 B3AR stimulation reverses memory deficits in 16-month-old 3xTg-AD. a Description of the novel object recognition test. Recognition indexes (RI) assessed before (14-month-old mice) and after (16-month-old mice) the treatment with CL-316,243 or saline in b NonTg and c 3xTg$\mathrm{AD}$ mice. $\mathbf{d}$ Final recognition index, e time spent exploring the old $(\mathrm{O})$, and the novel $(\mathrm{N})$ object during the 5-min acquisition phase and $\mathbf{f}$ total observations measured at the end of the experiment (final, 16-month-old mice). $\mathbf{g}$ Correlation between the \% change in recognition index (the change in RI before versus after the treatment) and UCP1 levels measured in BAT. $\mathbf{h}$ Representation of the open field apparatus. $\mathbf{i}$ Total distance traveled and $\mathbf{j}$ average speed during the 1-h test. $\mathbf{k}$ Representation of the dark-light emergence test. I Time spent in the light compartment and $\mathbf{m}$ latency before the first exploration in the light compartment. Recognition index $=$ (time exploring the novel object / total exploration time) $\times$ 100. Data are represented as mean \pm SEM ( $n$ /group indicated in graphics). Statistics: Paired t-test (baseline versus final recognition index (b, c); old (O) versus novel (N) object $(\mathbf{e}))$ : ${ }^{\$} p<0.05 ; \$ p<0.01$ (b, c, e); ns: non-significant compared to recognition index at baseline (b, $\left.\mathbf{c}\right)$. Dotted red line: $50 \% \mathrm{Rl}$ corresponds to an equal (random) exploration between the novel and the familiar object. One sample $t$-test versus $50 \%$ (random chance): ${ }^{\# \#} p<0.01$ (d). Pearson $r$ correlation: ${ }^{*} p<0.05$ (g). Two-way ANOVA, effect of genotype: \&\& $p<0.01$ (j, m). Two-way ANOVA, effect of genotype or treatment: ns (d). Abbreviations: 3xTg-AD: triple transgenic mice; CL: CL-316,243-injected group; eEF2: eukaryotic elongation factor 2; NonTg: nontransgenic mice; O.D.: optical density; S: saline-injected group; UCP1: uncoupling protein 1

50\%: $p=0.0013$ ), but not in NonTg mice (Fig. 3d). The improved RI in 3xTg-AD-treated mice was confirmed by the higher time spent on the novel $(\mathrm{N})$ versus the familial (O) object (Fig. 3e). These differences were not explained by changes in exploratory behavior, as the mean duration of exploration was similar between groups (Fig. 3f). Finally, the percent change in RI before and after the treatment was positively correlated with UCP1 levels in BAT in $3 x \mathrm{Tg}-\mathrm{AD}\left(r^{2}=0.37\right)$ but not in NonTg mice, suggesting a link between improved thermogenesis and memory (Fig. 3g).

We then verified that locomotor activity was not affected by CL-316,243 injections, as showed by comparable distance traveled and average speed of the mice during the open field test (Fig. $3 \mathrm{~h}-\mathrm{j}$ ). Nonetheless, 2 -way ANOVA revealed that 3xTg-AD mice displayed a higher average speed during the $1-\mathrm{h}$ session compared to NonTg mice (Fig. 3j).

Anxiety is frequently observed in $\mathrm{AD}$ patients and has been replicated in $3 x T g-A D$ mice $[9,46,66]$. The time spent in the illuminated compartment was not significantly different between groups in the present cohorts of animals (Fig. 3l). However, 3xTg-AD mice delayed their first exploration in the light chamber, as measured by the latency of the first nose entry in the light compartment (nose poke latency) (Fig. 3m), corroborating an anxiety-like behavior in this model.

Overall, 1-month administration of CL-316,243 improved recognition memory assessed at 16 months in $3 x \mathrm{Tg}-\mathrm{AD}$ mice, without affecting locomotion nor anxiety-like behavior.

\section{$\beta 3 A R$ stimulation reduces insoluble $A \beta 42 / A \beta 40$ ratio in the hippocampus of 3xTg-AD mice}

The main neuropathological markers of $\mathrm{AD}$, amyloid plaques and tau pathology $[67,68]$, progressively develop in the brain of $3 x \mathrm{Tg}-\mathrm{AD}$ mice [44, 45, 47]. Although total $A \beta 42$ and $A \beta 40$ peptides in either soluble or insoluble fractions remained unchanged by the treatment in the hippocampus (Fig. 4a-e), we observed a $27 \%$ decrease in
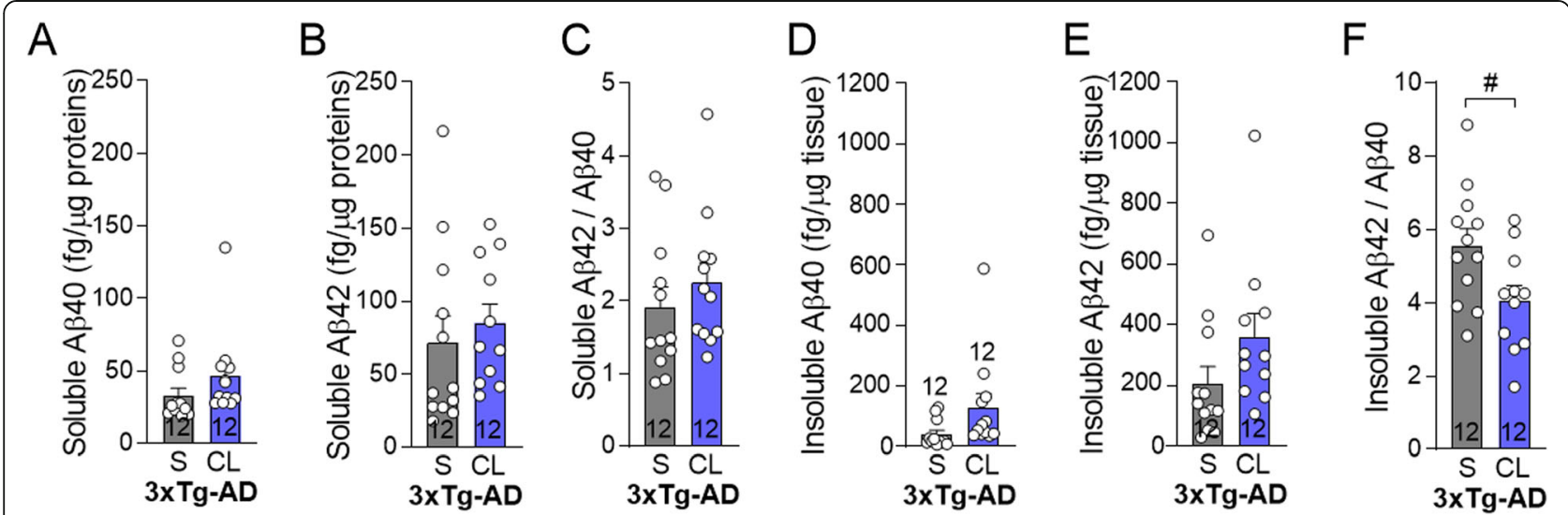

Fig. $4 \beta 3 A R$ stimulation reduces insoluble $A \beta 42 / A \beta 40$ ratio in the hippocampus of $3 x T g-A D$ mice. Human $A \beta 40$ and $A \beta 42$ peptides measured by ELISA in the $\mathbf{a}, \mathbf{b}$ detergent-soluble and in the $\mathbf{d}$, e detergent-insoluble fractions of hippocampus homogenates of $3 \times T g$-AD mice, respectively. $\mathbf{c}$ Ratio of detergent-soluble and $\mathbf{f}$ detergent-insoluble A 42 on A 340 peptides in the hippocampus. Data are represented as mean \pm SEM ( $n / g r o u p$ indicated in bars). Statistics: Unpaired Student's $t$ test: ${ }^{\#} p<0.05$ (a-e). Abbreviations: 3xTg-AD: triple transgenic mice; Aß: amyloid- $\beta$; $C L$ : CL316,243-injected group; NonTg: non-transgenic mice; S: saline-injected group 
insoluble $A \beta 42 / A \beta 40$ ratio in $C L-316,243$-treated mice compared to saline-injected 3xTg-AD mice (Fig. 4f). We subsequently assessed the effect of the B3AR agonist on proteins implicated in the production (beta-secretase 1 (BACE-1), amyloid precursor protein (APP), APP Cterminal, sAPP $\alpha$ ) and clearance or degradation (low density lipoprotein receptor related protein 1 (LRP1), receptor of advanced glycation end products (RAGE), insulindegrading enzyme (IDE), X11 $\alpha$ ) of $A \beta$ peptides (Additional File 2) $[67,69,70]$. Levels of BACE-1, IDE, LRP1, and RAGE in the hippocampus did not differ between groups, whereas those of X11 $\alpha$ were lower in 3xTg-AD mice compared to NonTg mice (Additional File 2) as observed in the brain of AD individuals [61].

We then assessed the level of phosphorylated and total tau protein in the detergent-soluble (cytosolic and membrane proteins) and detergent-insoluble (aggregated proteins) fractions of hippocampus homogenates by Western Blot. We did not find any significant effect of CL-316,243 (Fig. 5) but confirmed that the 3xTg-AD mice display higher total and hyperphosphorylated tau proteins compared to NonTg mice. Main kinases involved in tau phosphorylation (glycogen synthase kinase $3 \beta$ (GSK3 $\beta$ ) and protein kinase B known as AKT) were also unchanged (Additional File 2).

Synaptic deficits are one of the earliest markers of AD, correlating with symptoms $[61,71]$. The levels of synaptic proteins were not modified by the treatment (Additional File 2). However, drebrin protein was decreased specifically in 3xTg-AD mice (two-way ANOVA, effect of genotype: $p=0.0045$ ), as previously showed in the brain of AD subjects [72, 73].

Since glucose transporters and uptake are decreased in $\mathrm{AD}[21,74-76]$, we assessed glucose transporter 1 (GLUT1) levels in the hippocampus of the mice. While we did not detect any effect of the CL-316,243 treatment, GLUT1 levels were decreased in the hippocampus of 3xTg-AD mice compared to NonTg mice, at both the endothelial $(50 \mathrm{kDa})$ and astrocytic $(45 \mathrm{kDa})$ isoforms (Additional File 2), corroborating defects in glucose uptake, changes in blood-brain barrier transporters, and decreased cerebral vascular volume observed in this mouse model of AD [77-80].

\section{Discussion}

The present study aimed at investigating whether $\beta 3 A R$ agonist administration enhances BAT thermogenesis and exerts an effect on cognitive behavior and $\mathrm{AD}$ neuropathology in a mouse model of the disease. The $3 x T g-A D$ mice was selected to test the effect of $\beta 3 A R$ stimulation in $\mathrm{AD}$ because this model displays agedependent metabolic and thermoregulatory deficits and was shown to respond to thermoneutrality and BAT stimulation induced by repeated cold exposure $[8,9,16]$.
This led to the hypothesis that pharmacological BAT stimulation could exert benefits on AD-like behavior and neuropathology.

As a proof of concept, we previously reported that modulating ambient temperature affect AD neuropathology and behavior in mice [9]. It could thus be tempting to deduce that alleviating $\mathrm{AD}$ pathogenesis in the elderly can be achieved simply by "turning up the heat." However, this strategy would probably be inefficient in the long term. Indeed, such as a muscle during exercise, the BAT needs to be trained and prepared to maintain thermogenic capacity continuously [28]. Exposing mammals to a constant thermoneutral environment may induce BAT regression due to no recruitment, letting the organism vulnerable to any further temperature challenge and even inducing subtle hypothermia, leading to aggravated AD neuropathology. Therefore, chronic BAT stimulation, naturally or through a pharmacological intervention, would have the advantage to protect against potential hypothermic events by maintaining an optimal thermogenic capacity.

To test the hypothesis in an animal model of $\mathrm{AD}$, we thus treated 15-month-old NonTg and 3xTg-AD mice with the selective 33 AR agonist CL-316,243 or saline for a month. We found that chronic administration of the agonist stimulated BAT thermogenesis and improved glucose homeostasis. Enhanced thermogenesis was associated with improved recognition memory in 16 months $3 \times \mathrm{Tg}-\mathrm{AD}$ mice and reduced insoluble $\mathrm{A} \beta 42 / \mathrm{A} \beta 40$ ratio in the hippocampus, while tau pathology remained unaffected.

\section{B3AR agonist: a two in one strategy to target both metabolic and thermoregulatory defects}

The most well-known characteristic of CL-316,243 is to improve metabolic disorders through enhanced BAT activity [36-40]. Whether this effect is maintained with age remains unknown. UCP1 and NADH dehydrogenase 1 beta subcomplex subunit 8 (NDUFB8 or Complex I) are both recognized markers of BAT activation (Nam and Cooper, 2015). Higher levels of UCP1 and Complex I in the BAT detected here indicate a sustained effect of CL-316,243 on BAT thermogenesis after a 1-month chronic treatment in old mice. This is consistent with strong previous evidence that $\beta 3 \mathrm{AR}$ stimulation leads to increased thermogenic activity of BAT in young mice (Labbé et al., 2016; Poher et al., 2015; Xiao et al., 2015) and humans as well $[41,81]$. It also shows that chronic B3AR administration does not induce significant receptor desensitization, despite decreased levels of BAT $\beta 3 A R$ following treatment, in agreement with previous works [82]. Overall, our data now confirms that B3ARinduced thermogenesis is still effective in a 15-month- 


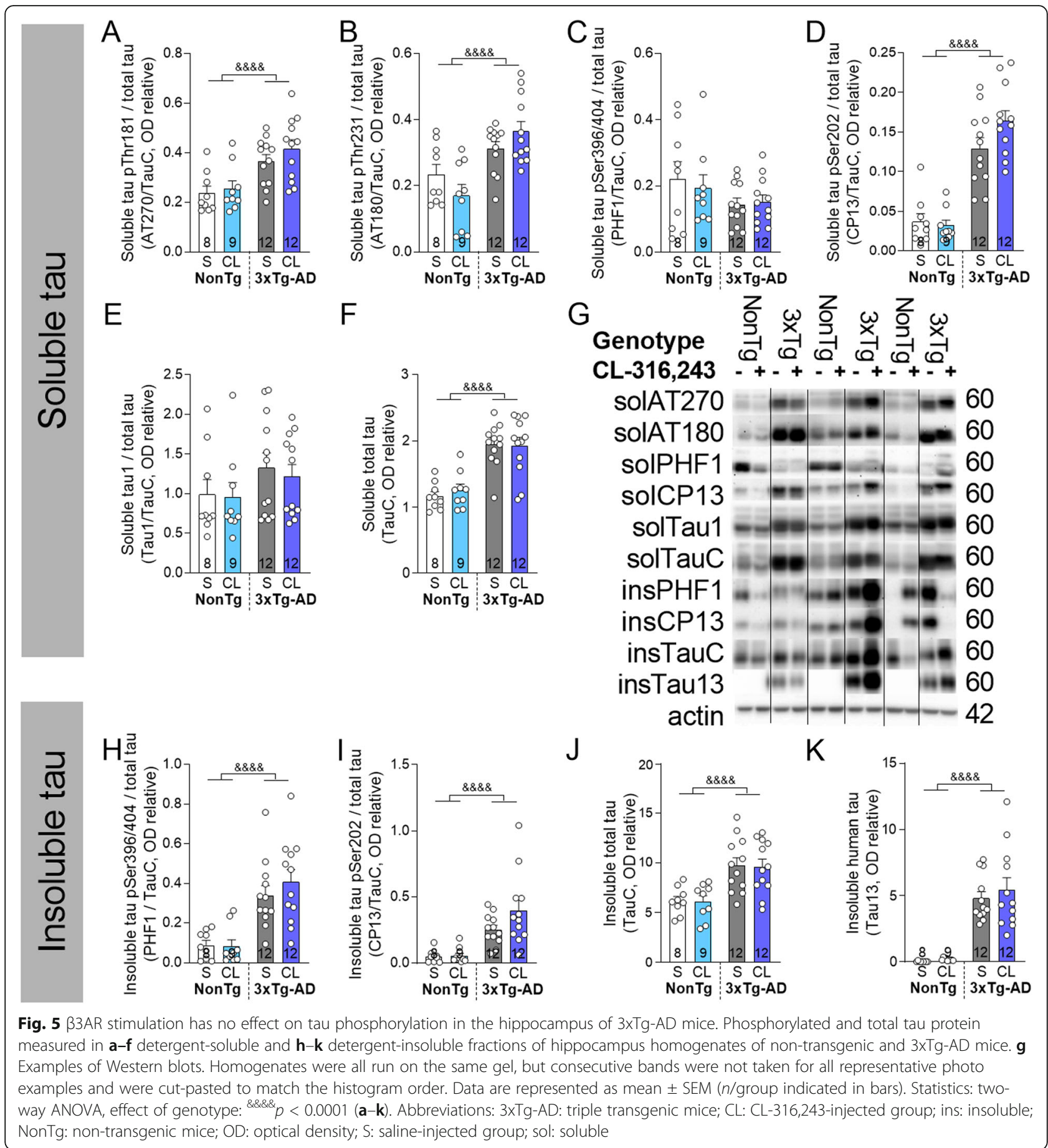

old mouse, following a 1-month treatment with CL-316, 243 , regardless of the presence of AD neuropathology.

White adipose tissue "beiging" (i.e., white adipocyte expressing UCP1) is another marker of enhanced thermogenesis in rodents [83] which could be investigated after CL-316,243 treatment. However, compared to BAT activity, "beige" cell contribution to thermogenesis is negligible [39]. Nevertheless, in the present study,
B3AR agonist induced weight loss in both NonTg and 3xTg-AD mice, suggesting increased lipolysis. Food consumption was higher in 3xTg-AD compared to NonTg mice, an observation previously reported in this model $[84,85]$, and CL-316,243 increased food intake in NonTg mice. These data are consistent with increased energetic expenditure compensated with higher calorie intake following $33 \mathrm{AR}$ stimulation $[64,86]$. 
We previously showed that female $3 x T g-A D$ mice display age-dependent glucose intolerance starting from 12 months [47]. While the difference in glucose tolerance between NonTg and 3xTg-AD mice was not frank in the present work, probably due to the fact that only males were used, fasting blood glucose in 3xTg-AD was higher than in NonTg mice. It is noteworthy that the CL-316, 243 improved peripheral glucose metabolism and fasted insulin in 16-month-old mice of both genotypes, suggesting an effect independent of AD neuropathology. Of note, the improvement was observed in mice fed with a diet not expected to induce metabolic defects, suggesting benefits even in non-diabetic animals. This is in line with a previous study showing improved glucose metabolism with CL-316,243 administration even in mice displaying a normal response to glucose [64]. Thus, a $33 \mathrm{AR}$ agonist treatment could also benefit elderly individuals without diabetes.

Using hourly telemetric recordings of body temperature, we noted that 3xTg-AD mice displayed wider amplitudes of body temperature throughout the day compared to NonTg mice. On the other hand, $\beta 3 \mathrm{AR}$ agonist treatment increased amplitude of body temperature during the light phase, corresponding to the period of drug administration, but not during the dark phase. The wider amplitude in body temperature is consistent with a higher body temperature after CL-316,243 injection, as shown by the temperature recorded few hours after the first i.p. injection and a previous work [87]. However, we did not observed chronic hyperthermia, which would have been a major side effect of $\beta 3 A R$ agonists, perhaps compromising potential translation to clinical use.

\section{B3AR stimulation reverses memory deficits in old $3 \times \mathrm{Tg}$ - AD mice}

An important result of our study is the reversal of recognition memory deficit induced by $\beta 3 \mathrm{AR}$ stimulation in 16-month-old 3xTg-AD mice. Indeed, we observed a $19 \%$ increase of RI between baseline (14 months) and post-treatment evaluation (16 months). These results were not explained by changes in exploratory behavior or locomotor activity. The RI of NonTg mice following treatment did not reach statistical significance perhaps due to lower statistical power $(n=5)$, but was significantly different from $50 \%$ in saline-injected mice. Although a downward trend was noted, the RI of the NonTg group treated with CL-316,243 was not significantly different after versus before the treatment. However, the high interindividual variability and the low number of mice in the group prevent us to draw a conclusion concerning potential positive or negative effects in NonTg mice. Reassuringly, a recent study shows no negative effect on the memory performance after a 3- month treatment with mirabegron in patients with overactive bladder aged $\geq 65$ years [88]. Nevertheless, the data also suggest that $\beta 3 \mathrm{AR}$-induced improvement in memory was specific to $3 x \mathrm{Tg}$-AD mice, possibly through an effect related to $\mathrm{AD}$ neuropathology. As only 3xTg$\mathrm{AD}$ mice develop $\mathrm{A} \beta$ plaques or neurofibrillary tangles, if CL-316,243 exerted an AD-relevant effect on $A \beta$ and tau pathologies, it would be detected only in $3 x T g-A D$ mice. This may explain the present difference in response between NonTg and 3xTg-AD mice. Indeed, regarding the effects of $\mathrm{CL}-316,243$ administration on classical AD neuropathology, we observed a reduction in the $A \beta 42: A \beta 40$ ratio within insoluble deposits, which is only quantifiable in transgenic mice. Importantly, the randomized-start design ensured that all groups of animals were similar before undergoing saline or CL-316, 243 treatment. One study also found memory improvement following CL-316,243 administration in $\mathrm{A} \beta$ injected chicks [89], but no previous report in mice was found in the literature. Thus, our results are consistent with a disease-modifying effect of $\beta 3 A R$ stimulation in the 3xTg-AD mice.

Since metabolic disorders also alter cognitive function and lead to memory defects [90-94], improved peripheral metabolism could be involved in better recognition memory in 3xTg-AD mice. However, it is not excluded that CL-316,243 has a direct effect in the CNS. Indeed, $\beta 3 A R$ are present in various regions of the brain, although to a much lower extent compared to the BAT $[95,96]$, but their physiological roles in the central nervous system (CNS) are not known. While it has been shown that CL-316,243 increases sleep duration in mice [87] and reduces $A \beta$-induced long-term memory deficits in chicks [89], the behavioral effects of $\beta 3 \mathrm{AR}$ agonists has not been the subject of intense investigation. Nonetheless, another B3AR agonist, SR856611A (Amibegron $^{\circ}$ ), has been shown to improve anxiety and depressive-like symptoms in rodents, as evaluated by the forced swim test and the elevated plus maze [97-99]. This promising molecule reached phase III clinical trial for depression (NCT00252330) but did not achieve final approval to move into the clinic. In the present work, we did not detect changes in anxiety-like behavior with the dark-light emergence test following CL-316,243 administration. Recently, a group reported no change in MoCA score in a group of elderly receiving mirabegron (Myrbetriq ${ }^{\odot}$ ) as a treatment for overactive bladder for 3 months [88]. However, only 115 volunteers with impaired cognitive performance received the treatment, and 3 months might be too short to detect any potential cognitive benefits [100]. While the effects of $\beta 3 A R$ agonists on the brain are not yet clearly understood, what stand up from our data is that enhanced UCP1 levels in BAT were correlated with higher improvement in RI in 3xTg-AD 
mice, supporting the idea that higher BAT thermogenesis induced by B3AR stimulation is involved in improved memory performance.

\section{$\beta 3 A R$ stimulation decreases insoluble $A \beta 42 / A \beta 40$ ratio but has no effect on tau phosphorylation in the hippocampus of 3xTg-AD mice}

The 3xTg-AD model allowed us to probe whether the effect of CL-316,243 are related to changes in AD neuropathology. Despite no change in total tau or $A \beta$ burden, a $27 \%$ decrease in insoluble $A \beta 42 / A \beta 40$ ratio was observed in the hippocampus of old 3xTg-AD mice following CL-316,243 injections. We did not observe concomitant changes in $\mathrm{A} \beta 40, \mathrm{~A} \beta 42, \mathrm{BACE} 1, \mathrm{APP}, \mathrm{IDE}$, or LRP1. Although no clear mechanism can be identified from our study, genetic data strongly suggest that a treatment reducing the $A \beta 42 / A \beta 40$ ratio in the hippocampus is consistent with a beneficial impact on $A \beta$ production and aggregation [101, 102]. $A \beta 42 / A \beta 40$ ratio in the brain has been consistently associated with higher risk of developing $\mathrm{AD}$, at least in genetic cases. Indeed, the $A \beta 42 / A \beta 40$ ratio is increased in familial forms of $\mathrm{AD}$ and is inversely correlated with the age of onset of the disease $[103,104]$. Decreased $A \beta 42 / A \beta 40$ ratio suggests a shift in APP cleavage from $A \beta 42$ to $A \beta 40$, which is less prone to aggregation than $A \beta 42$. Importantly, increased $A \beta 42 / A \beta 40$ ratio precedes amyloid plaques formation in the Tg2576 mouse model of AD [105]. More recent work using induced pluripotent stem cells (iPSC) corroborates this view, indicating that APP or presenilin 1 (PSEN1) mutations, the more likely to cause familial $A D$, also leads to higher $A \beta 42 / A \beta 40$ ratio [106]. Consistent with biochemical data in cellular models, recent clinical studies suggest that CSF and plasma $A \beta$ ratios are biomarkers of $A \beta$ processing and can be useful in the diagnosis of $\mathrm{AD}[101,107]$.

The absence of changes on the phosphorylation status of tau following CL-316,243 administration could be interpreted as surprising. Since tau phosphorylation has been repeatedly shown to follow body temperature modulation [12-14], we could have expected a protective effect of $\beta 3 A R$ stimulation. We observed a transitory increase in temperature following CL-316,243 injection, but this effect was only temporary and thus did not impact tau phosphorylation measured at the end of the experiment. As mentioned above, CL-316,243 did not induce chronic hyperthermia, which would actually be an adverse effect. In contrast, we recently showed that improved BAT thermogenesis through repeated cold exposure protects old 3xTg-AD mice from cold-induced tau phosphorylation [16]. However, the present study design did not fully explore the hypothesis that B3AR stimulation impacts tau phosphorylation, because the animals were kept at room temperature and not exposed to any frank thermoregulatory challenge (i.e., acute 24-h exposure to cold). Thus, because it has not been directly tested in the present study, it remains possible that pharmacological $\beta 3 A R$ stimulation also confers protection against cold-induced tau phosphorylation.

\section{Limitations}

Limitations of the current work include the absence of confirmation that CL-316,243 crosses the blood-brain barrier and had a direct effect in the CNS of mice. However, as stated above, reaching the brain is not absolutely required to exert benefits, as the prime target of $\beta 3 \mathrm{AR}$ agonists is the BAT. Another limitation is the low number of mice in the NonTg group that met the inclusion criteria of minimal exploring time to be included in the NOR test, preventing us to draw conclusion on a potential effect of $\beta 3 A R$ agonist on old control (NonTg) mice. However, our several previous studies showed that this memory test is appropriate and adapted for old 3xTg$\mathrm{AD}$ mice, because it is less affected by other variables failing with age in these types of models, such as thermoregulation, sensorimotor performance, and anxiety. Furthermore, the effect of a $\beta 3 A R$ agonist was evaluated in only one mouse model of $\mathrm{AD}$, the $3 \times \mathrm{Tg}-\mathrm{AD}$ mouse model of $\mathrm{AD}$. It is important to note that there is no true mouse model of sporadic $\mathrm{AD}$ available. Although the triple transgenic mice is a model generated by the overexpression of three human mutations found in familial forms of $\mathrm{AD}$, it is the only one that recapitulates both progressive tau and $A \beta$ pathologies as well as thermoregulatory and metabolic impairments [9, 44]. However, it would be interesting to investigate the effect of a $\beta 3 A R$ agonist in other recently developed murine models of tau or $A \beta$ pathologies [108]. Finally, we used only males to avoid temperature variations induced by the estrous cycle of female mice, but since female $3 \mathrm{xTg}$ $\mathrm{AD}$ mice develop aggravated metabolic deficits as well as higher $A \beta$ pathology compared to males, the benefit of the treatment observed could have been more prominent in females.

\section{Conclusions}

The present work aimed to determine whether $\beta 3 \mathrm{AR}$ agonists exert positive effects on AD-relevant endpoints in an animal model of tau and $A \beta$ neuropathology, thereby providing arguments for drug repurposing in AD. This class of drugs is actively being tested in clinical studies for metabolic diseases [109, 110] and CL-316,243 has been previously investigated in humans as well [111]. As an example, mirabegron (Myrbetriq ${ }^{\circ}$ ) has been approved by the Food and Drug Administration for the treatment of overactive bladder [41, 112], and large randomized controlled trials have confirmed its safety and tolerability profiles [113], even in the elderly population [114]. Thus, 
the potential translation to clinical use of this class of drugs in AD is high. Nonetheless, it has to be noted that in humans, potential side effects of $\beta 3 A R$ agonists include cardiovascular dysfunction induced by nonspecific activation of $\beta 1$ and $\beta 2$ adrenergic receptors. Indeed, a single administration of mirabegron at a dose of $200 \mathrm{mg}$ (fourth times the clinical dose) enhances BAT activity in adults, but also induced cardiac arrhythmia in a few cases [41]. While the clinical dose of $50 \mathrm{mg}$ does not seem to be efficient to acutely stimulate BAT [42], a recent study showed that $100 \mathrm{mg}$ of mirabegron enhances thermogenesis without any cardiovascular side effects in adults [81]. Yet, long-term studies investigating chronic effect of $\beta 3 \mathrm{AR}$ agonists in BAT thermogenesis in old volunteers are needed.

Altogether, our results in a mouse model of AD demonstrate for the first time that $\beta 3 \mathrm{AR}$ agonists are potent tools to reverse memory deficits and insoluble $A \beta 42 /$ A $\beta 40$ ratio in the hippocampus. It is the first study to our knowledge to investigate the potential of this class of drugs on AD neuropathology and behavior.

\begin{abstract}
Abbreviations
3xTg-AD: Triple transgenic mouse model of AD; $\beta 3 A R: \beta 3$ adrenergic receptor; $A B$ : Amyloid- $\beta$; AD: Alzheimer's disease; AKT: Protein kinase $B$; APP: Amyloid precursor protein; AUC: Area under curve; BACE-1: Betasecretase 1; BAT: Brown adipose tissue; CV, CIII, CIV, CII, Cl: Mitochondrial oxidative phosphorylation system complex V, III, IV, II, I; DL: Dark-light emergence test; eEF2: Eukaryotic elongation factor 2; GFAP: Glial fibrillary acidic protein; GLUT1: Glucose transporter 1; GSK3 $\beta$ : Glycogen synthase kinase 3 ; GT: Glucose tolerance test; IDE: Insulin degrading enzyme; LRP1: Low-density lipoprotein receptor related protein 1; NonTg: Nontransgenic mice; NOR: Novel object recognition test; OD: Optical density; OF: Open field test; PSD95: Post-synaptic density 95; PSEN1: Presenilin 1; RAGE: Receptor of advanced glycation end products; RI: Recognition index; SAPPa: soluble a-APP; T: Temperature; T2D: Type 2 diabetes;

UCP1: Uncoupling protein 1
\end{abstract}

\section{Supplementary Information}

The online version contains supplementary material available at https://doi. org/10.1186/s13195-021-00842-3.

Additional file 1. CL-316,243 administration does not affect circadian rhythm parameters nor BAT norepinephrine content. A: individual mean daily offsets (determined as the time of the first six successive bins when temperature was lower than the mean diurnal temperature, thus corresponding to morning temperature drop). B: Offset standard deviation. C: Mean duration of a total temperature cycle. D: Mean amplitude of body temperature during one day (24-h, from 7 a.m. to 7 p.m.). E: Norepinephrine concentrations measured by HPLC in BAT, normalized to tissue weights. Data are represented as mean \pm SEM ( $n /$ group indicated in bars). Statistics: Two-way ANOVA, effect of CL-316,243 treatment: ${ }^{* * * *} p<0.0001$, effect of genotype: ${ }^{{ }^{*}} p<0.05^{{ }^{8 \& \& \&}} p<0.0001$ (A-E). Abbreviations: 3xTg-AD: triple transgenic mice; CL: CL-316,243injected group; NonTg: non-transgenic mice; S: saline-injected group

Additional file 2. Other AD markers not affected by CL-316,243 treatment. Relative optical density of proteins normalized on actin measured in detergent-soluble fraction of hippocampus homogenates by Western Blot. Data are represented as mean $\pm S D, n=9-12$ per group. Abbreviations: AKT: protein kinase B; APP: amyloid precursor protein; BACE-1: betasecretase 1; GFAP: glial fibrillary acidic protein; GLUT1: glucose transporter 1; GSK3 $\beta$, glycogen synthase kinase 3 $\beta$; IDE: insulin degrading enzyme;
LRP1: low density lipoprotein receptor related protein 1; PSD95: postsynaptic density 95; RAGE: receptor of advanced glycation end products; sAPPa: soluble a-APP

Additional file 3. Antibodies used in this study

\section{Acknowledgements}

The authors are grateful to Patrick Caron and Chantal Guillemette for technical support and to Isabelle Guisle for comments on the manuscript. The authors thank the animal facility technicians Sonia Francoeur, Stéphanie Bernard, and France Duclos for their help during the animal experiment.

\section{Authors' contributions}

M.T. designed the study, performed animal experiments, drug administration, behavior and metabolic evaluations, protein extractions, Western blots, immunohistochemistry, HPLC, completed the statistical analysis, interpretation of the data, and wrote the manuscript. T.V. contributed to animal experiments and western blots. N.V. performed Western blots and contributed to protein extractions. C.H. and F.P. performed chronobiology analysis on body temperature and reviewed the manuscript. C.T. performed $A \beta$ quantification. K.M. contributed to norepinephrine extraction and measurement. E.P. provided expertise for the tau analysis and reviewed the manuscript. F.C. secured funding, contributed to the experimental design, and wrote the manuscript. F.C. is the guarantor of this work and, as such, had full access to all the data in the study and takes responsibility for the integrity of the data and the accuracy of the data analysis. All authors reviewed and approved the final manuscript.

\section{Funding}

M.T. was funded by a scholarship from the Alzheimer Society of Canada. This study was made possible by funding from the Alzheimer Society of Canada (\#15-02 and \#20-01), the Canadian Institutes of Health Research (MOP 102532), the Quebec Network for Research on Aging, and the Canadian Foundation for Innovation (\#34480). F.C. and E.P are Fonds de Recherche du Québec - Santé (FRQ-S) scholars (\#253895, \#26936, and \#252178).

\section{Availability of data and materials}

The datasets generated and analyzed during the current study are available from the corresponding author on reasonable request.

\section{Declarations}

\section{Ethics approval and consent to participate}

All animal experiments were performed in accordance with the Canadian Council on Animal Care and were approved by the Institutional Committee of the Centre Hospitalier de I'Université Laval (CHUL).

\section{Consent for publication}

Not applicable.

\section{Competing interests}

The authors declare that they have no competing interests.

\section{Author details}

${ }^{1}$ Faculté de pharmacie, Université Laval, 1050 Avenue de la Médecine, Quebec, QC G1V 0A6, Canada. ²Axe Neurosciences, Centre de recherche du CHU de Québec-Université Laval (Pavillon CHUL), 2705 Boulevard Laurier, Quebec, QC G1V 4G2, Canada. ${ }^{3}$ UMR CNRS/MNHN 7179, Mécanismes Adaptatifs et Évolution, 1 Avenue du Petit Château, 91800 Brunoy, France. ${ }^{4}$ Département de psychiatrie et neurosciences, Faculté de médecine, Université Laval, 1050 Avenue de la Médecine, Quebec, QC G1V 0A6, Canada.

Received: 25 February 2021 Accepted: 4 May 2021

Published online: 21 May 2021

\section{References}

1. Scheltens P, Blennow K, Breteler MMB, De Strooper B, Frisoni GB, Salloway S, et al. Alzheimer's disease. Lancet. 2016;388(10043):505-17. https://doi.org/1 0.1016/S0140-6736(15)01124-1.

2. Querfurth HW, LaFerla FM. Alzheimer's disease. N Engl J Med. 2010;362(4): 329-44. https://doi.org/10.1056/NEJMra0909142. 
3. Winblad B, Amouyel P, Andrieu S, Ballard C, Brayne C, Brodaty H, et al. Defeating Alzheimer's disease and other dementias: a priority for European science and society. Lancet Neurol. 2016;15(5):455-532. https://doi.org/10.1 016/S1474-4422(16)00062-4.

4. Degroot DW, Kenney WL. Impaired defense of core temperature in aged humans during mild cold stress. Am J Physiol Regul Integr Comp Physiol. 2007;292:R103-8

5. Grassi G, Seravalle G, Turri C, Bertinieri G, Dell'Oro R, Mancia G. Impairment of thermoregulatory control of skin sympathetic nerve traffic in the elderly. Circulation. 2003;108:729-35 Lippincott Williams \& Wilkins.

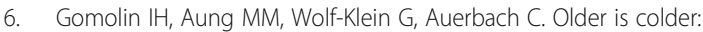
temperature range and variation in older people. J Am Geriatr Soc. 2005; 53(12):2170-2. https://doi.org/10.1111/j.1532-5415.2005.00500.x Blackwell Science Inc.

7. Hebert LE, Weuve J, Scherr PA, Evans DA. Alzheimer disease in the United States (2010-2050) estimated using the 2010 census. Neurology. 2013;80(19): 1778-83. https://doi.org/10.1212/WNL.0b013e31828726f5.

8. Knight EM, Brown TM, Gümüsgöz S, Smith JCM, Waters EJ, Allan SM, et al. Age-related changes in core body temperature and activity in tripletransgenic Alzheimer's disease (3xTgAD) mice. Dis Model Mech. 2013;6:16070 The Company of Biologists Limited.

9. Vandal M, White PJ, Tournissac M, Tremblay C, St-Amour I, Drouin-Ouellet J, et al. Impaired thermoregulation and beneficial effects of thermoneutrality in the $3 \times$ Tg-AD model of Alzheimer's disease. Neurobiol Aging. 2016;43: 47-57. https://doi.org/10.1016/j.neurobiolaging.2016.03.024.

10. Sterniczuk R, Dyck RH, LaFerla FM, Antle MC. Characterization of the 3xTgAD mouse model of Alzheimer's disease: part 1. Circadian changes. Brain Res. 2010;1348:139-48. https://doi.org/10.1016/j.brainres.2010.05.013.

11. Huitrón-Reséndiz S, Sánchez-Alavez M, Gallegos R, Berg G, Crawford E, Giacchino $J$, et al. Age-independent and age-related deficits in visuospatial learning, sleep-wake states, thermoregulation and motor activity in PDAPP mice. Brain Res. 2002;928(1-2):126-37. https://doi.org/1 0.1016/S0006-8993(01)03373-X.

12. Planel E, Richter KEG, Nolan CE, Finley JE, Liu L, Wen $Y$, et al. Anesthesia leads to tau hyperphosphorylation through inhibition of phosphatase activity by hypothermia. J Neurosci. 2007;27(12):3090-7. https://doi.org/10.1 523/JNEUROSCI.4854-06.2007 Society for Neuroscience.

13. Arendt T, Stieler J, Strijkstra AM, Hut RA, Rüdiger J, Van der Zee EA, et al. Reversible paired helical filament-like phosphorylation of tau is an adaptive process associated with neuronal plasticity in hibernating animals. J Neurosci. 2003;23(18):6972-81. https://doi.org/10.1523/JNEUROSCI.23-1806972.2003

14. Stieler JT, Bullmann T, Kohl F, Tøien $\varnothing$, Brückner MK, Härtig W, et al. The physiological link between metabolic rate depression and tau phosphorylation in mammalian hibernation. PLoS One. 2011;6:e14530.

15. Tournissac M, Vandal M, Francois A, Planel E, Calon F. Old age potentiates cold-induced tau phosphorylation: linking thermoregulatory deficit with Alzheimer's disease. Neurobiol Aging. 2017;50:25-9. https://doi.org/10.1016/j. neurobiolaging.2016.09.024.

16. Tournissac M, Bourassa P, Martinez-Cano RD, Vu T-M, Hébert SS, Planel E, et al. Repeated cold exposures protect a mouse model of Alzheimer's disease against cold-induced tau phosphorylation. Mol Metab. 2019;22:11020. https://doi.org/10.1016/j.molmet.2019.01.008.

17. Vandal M, White PJ, Tremblay C, St-Amour I, Chevrier G, Emond V, et al. Insulin reverses the high-fat diet-induced increase in brain $a \beta$ and improves memory in an animal model of Alzheimer disease. Diabetes. 2014;63:4291301 American Diabetes Association.

18. Gratuze M, Julien J, Petry FR, Morin F, Planel E. Insulin deprivation induces PP2A inhibition and tau hyperphosphorylation in hTau mice, a model of Alzheimer's disease-like tau pathology. Sci Rep. 2017;7:46359 Nature Publishing Group.

19. Julien C, Tremblay C, Phivilay A, Berthiaume L, Emond V, Julien $P$, et al High-fat diet aggravates amyloid-beta and tau pathologies in the 3xTg-AD mouse model. Neurobiol Aging. 2010;31(9):1516-31. https://doi.org/10.1016/ j.neurobiolaging.2008.08.022.

20. Thériault $P$, ElAli A, Rivest $S$. High fat diet exacerbates Alzheimer's diseaserelated pathology in APPswe/PS1 mice. Oncotarget. 2016;7(42):67808-27. https://doi.org/10.18632/oncotarget.12179.

21. An Y, Varma VR, Varma S, Casanova R, Dammer E, Pletnikova O, et al. Evidence for brain glucose dysregulation in Alzheimer's disease. Alzheimers Dement. 2018;14(3):318-29. https://doi.org/10.1016/j.jalz.2017.09.011.
22. Arnold SE, Arvanitakis Z, Macauley-Rambach SL, Koenig AM, Wang H-Y, Ahima RS, et al. Brain insulin resistance in type 2 diabetes and Alzheimer disease: concepts and conundrums. Nat Rev Neurol. 2018;14(3):168-81. https://doi.org/10.1038/nrneurol.2017.185 Nature Publishing Group.

23. Biessels GJ, Staekenborg S, Brunner E, Brayne C, Scheltens P. Risk of dementia in diabetes mellitus: a systematic review. Lancet Neurol. 2006;5(1): 64-74. https://doi.org/10.1016/S1474-4422(05)70284-2.

24. Yarchoan M, Arnold SE. Repurposing diabetes drugs for brain insulin resistance in Alzheimer disease. Diabetes. 2014;63:2253-61 American Diabetes Association.

25. Craft S, Baker LD, Montine TJ, Minoshima S, Watson GS, Claxton A, et al. Intranasal insulin therapy for Alzheimer disease and amnestic mild cognitive impairment: a pilot clinical trial. Arch Neurol. 2012;69(1):29-38. https://doi. org/10.1001/archneurol.2011.233 American Medical Association.

26. Liu J, Wang L-N, Jia J-P. Peroxisome proliferator-activated receptor-gamma agonists for Alzheimer's disease and amnestic mild cognitive impairment: a systematic review and meta-analysis. Drugs Aging. 2015;32(1):57-65. https:// doi.org/10.1007/s40266-014-0228-7 Springer International Publishing.

27. Gejl M, Gjedde A, Egefjord L, Møller A, Hansen SB, Vang K, et al. In Alzheimer's disease, 6-month treatment with GLP-1 analog prevents decline of brain glucose metabolism: randomized, placebo-controlled, double-blind clinical trial. Front Aging Neurosci. Frontiers. 2016:8:108.

28. Cannon B, Nedergaard J. Brown adipose tissue: function and physiological significance. Physiol Rev. 2004;84(1):277-359. https://doi.org/10.1152/ physrev.00015.2003.

29. Virtanen KA, Lidell ME, Orava J, Heglind M, Westergren R, Niemi T, et al. Functional brown adipose tissue in healthy adults. N Engl J Med. 2009; 360(15):1518-25. https://doi.org/10.1056/NEJMoa0808949.

30. Cypess AM, Lehman S, Williams G, Tal I, Rodman D, Goldfine AB, et al. Identification and importance of brown adipose tissue in adult humans. N Engl J Med. 2009;360(15):1509-17. https://doi.org/10.1056/ NEJMoa0810780.

31. Hanssen MJW, Hoeks J, Brans B, van der Lans AAJJ, Schaart G, van den Driessche JJ, et al. Short-term cold acclimation improves insulin sensitivity in patients with type 2 diabetes mellitus. Nat Med. 2015;21(8):863-5. https:// doi.org/10.1038/nm.3891.

32. Ravussin Y, Xiao C, Gavrilova O, Reitman ML. Effect of intermittent cold exposure on brown fat activation, obesity, and energy homeostasis in mice. Public Libr Sci. 2014;9:e85876.

33. Schrauwen $P$, van Marken Lichtenbelt WD. Combatting type 2 diabetes by turning up the heat. Diabetologia. 2016;59:2269-79 Springer Berlin Heidelberg.

34. Arch JRS. Challenges in $\beta(3)$-adrenoceptor agonist drug development. Ther Adv Endocrinol Metab. 2011;2(2):59-64. https://doi.org/10.1177/204201 8811398517.

35. Nedergaard J, Golozoubova V, Matthias A, Asadi A, Jacobsson A, Cannon B. UCP1: the only protein able to mediate adaptive non-shivering thermogenesis and metabolic inefficiency. Biochim Biophys Acta. 2001; 1504(1):82-106. https://doi.org/10.1016/S0005-2728(00)00247-4.

36. de Souza CJ, Hirshman MF, Horton ES. CL-316,243, a beta3-specific adrenoceptor agonist, enhances insulin-stimulated glucose disposal in nonobese rats. Diabetes. 1997;46(8):1257-63. https://doi.org/10.2337/dia b.46.8.1257.

37. Burkey BF, Dong M, Gagen K, Eckhardt M, Dragonas N, Chen W, et al. Effects of pioglitazone on promoting energy storage, not expenditure, in brown adipose tissue of obese fa/fa Zucker rats: comparison to $\mathrm{CL} 316,243$. Metabolism. 2000:49(10):1301-8. https://doi.org/10.1053/meta.2000.9524.

38. Kumar A, Shiloach J, Betenbaugh MJ, Gallagher EJ. The beta-3 adrenergic agonist $(\mathrm{CL}-316,243)$ restores the expression of down-regulated fatty acid oxidation genes in type 2 diabetic mice. Nutr Metab (Lond). 2015;12:8 BioMed Central.

39. Labbé SM, Caron A, Chechi K, Laplante M, Lecomte R, Richard D. Metabolic activity of brown, "beige," and white adipose tissues in response to chronic adrenergic stimulation in male mice. Am J Physiol Endocrinol Metab. 2016; 311(1):E260-8. https://doi.org/10.1152/ajpendo.00545.2015.

40. Kim H, Pennisi PA, Gavrilova O, Pack S, Jou W, Setser-Portas J, et al. Effect of adipocyte beta3-adrenergic receptor activation on the type 2 diabetic MKR mice. Am J Physiol Endocrinol Metab. 2006:290:E1227-36 American Physiological Society.

41. Cypess AM, Weiner LS, Roberts-Toler C, Franquet Elía E, Kessler SH, Kahn PA, et al. Activation of human brown adipose tissue by a $\beta 3$-adrenergic 
receptor agonist. Cell Metab. 2015;21(1):33-8. https://doi.org/10.1016/j. cmet.2014.12.009 Elsevier.

42. Baskin AS, Linderman JD, Brychta RJ, McGehee S, Anflick-Chames E, Cero $C$, et al. Regulation of human adipose tissue activation, gallbladder size, and bile acid metabolism by a $\beta 3$-adrenergic receptor agonist. Diabetes. 2018. https://doi.org/10.2337/db18-0462 American Diabetes Association.

43. Chapple CR, Cardozo L, Nitti WW, Siddiqui E, Michel MC. Mirabegron in overactive bladder: a review of efficacy, safety, and tolerability. Neurourol Urodyn. 2014;33(1):17-30. https://doi.org/10.1002/nau.22505.

44. Oddo S, Caccamo A, Shepherd JD, Murphy MP, Golde TE, Kayed R, et al. Triple-transgenic model of Alzheimer's disease with plaques and tangles. Neuron. 2003;39(3):409-21. https://doi.org/10.1016/50896-6273(03)00434-3.

45. Belfiore R, Rodin A, Ferreira E, Velazquez R, Branca C, Caccamo A, et al. Temporal and regional progression of Alzheimer' disease-like pathology in 3xTg-AD mice. Aging Cell. 2018;12:e12873 John Wiley \& Sons, Ltd (10.1111).

46. St-Amour I, Paré I, Tremblay C, Coulombe K, Bazin R, Calon F. IVlg protects the 3xTg-AD mouse model of Alzheimer's disease from memory deficit and A $\beta$ pathology. J Neuroinflammation. 2014;11:54 BioMed Central Ltd.

47. Vandal M, White PJ, Chevrier G, Tremblay C, St-Amour I, Planel E, et al. Age-dependent impairment of glucose tolerance in the 3xTg-AD mouse model of Alzheimer' disease. FASEB J. 2015;29(10):4273-84. https://doi. org/10.1096/fj.14-268482.

48. Bories C, Guitton MJ, Julien C, Tremblay C, Vandal M, Msaid M, et al. Sexdependent alterations in social behaviour and cortical synaptic activity coincide at different ages in a model of Alzheimer's disease. Public Libr Sci. 2012;7:e46111 Borchelt DR, editor.

49. Weinert D, Waterhouse J, Nevill A. Changes of body temperature and thermoregulation in the course of the ovarian cycle in laboratory mice. Biol Rhythm Res. 2004;35(3):171-85. https://doi.org/10.1080/0929101 0412331335724

50. Danysz W, Han Y, Li F, Nicoll J, Buch P, Hengl T, et al. Browning of white adipose tissue induced by the $B 3$ agonist $\mathrm{CL}-316,243$ after local and systemic treatment - PK-PD relationship. Biochim Biophys Acta. 2018; 1864(9):2972-82. https://doi.org/10.1016/j.bbadis.2018.06.007.

51. Ghorbani M, Shafiee Ardestani M, Gigloo SH, Cohan RA, Inanlou DN, Ghorbani P. Anti diabetic effect of $\mathrm{CL} 316,243$ (a $\beta 3$-adrenergic agonist) by down regulation of tumour necrosis factor (TNF-a) expression. Public Libr Sci. 2012;7:e45874.

52. Bloom JD, Dutia MD, Johnson BD, Wissner A, Burns MG, Largis EE, et al. Disodium (R,R)-5-[2-[[2-(3-chlorophenyl)-2-hydroxyethyl]-amino] propyl]-1,3benzodioxole-2,2-dicarboxylate (CL 316,243). A potent beta-adrenergic agonist virtually specific for beta 3 receptors. A promising antidiabetic and antiobesity agent. J Med Chem. 1992;35(16):3081-4. https://doi.org/10.1021/ jm00094a025.

53. Yoshida T, Sakane N, Wakabayashi Y, Umekawa T, Kondo M. Anti-obesity and anti-diabetic effects of $C L$ 316,243, a highly specific beta 3adrenoceptor agonist, in yellow KK mice. Life Sci. 1994;54(7):491-8. https:// doi.org/10.1016/0024-3205(94)00408-0.

54. Caron A, Labbé SM, Carter S, Roy M-C, Lecomte R, Ricquier D, et al. Loss of UCP2 impairs cold-induced non-shivering thermogenesis by promoting a shift toward glucose utilization in brown adipose tissue. Biochimie. 2017; 134:118-26. https://doi.org/10.1016/j.biochi.2017.01.006.

55. Dal-Pan A, Dudonné S, Bourassa P, Bourdoulous M, Tremblay C, Desjardins $Y$, et al. Cognitive-enhancing effects of a polyphenols-rich extract from fruits without changes in neuropathology in an animal model of Alzheimer's disease. J Alzheimers Dis. 2016;Preprint:1-21 Ghribi O, editor. IOS Press.

56. Clinton LK, Billings LM, Green KN, Caccamo A, Ngo J, Oddo S, et al. Agedependent sexual dimorphism in cognition and stress response in the 3xTg-AD mice. Neurobiol Dis. 2007;28(1):76-82. https://doi.org/10.1016/j. nbd.2007.06.013.

57. Arsenault D, Julien C, Tremblay C, Calon F. DHA improves cognition and prevents dysfunction of entorhinal cortex neurons in 3xTg-AD mice. PLoS One. 2011;6:e17397.

58. Wolf A, Bauer B, Abner EL, Ashkenazy-Frolinger T, Hartz AMS. A Comprehensive behavioral test battery to assess learning and memory in 129S6/Tg2576 mice. PLoS One. 2016;11:e0147733 Reddy H, editor.

59. Leger M, Quiedeville A, Bouet V, Haelewyn B, Boulouard M, Schumann-Bard P, et al. Object recognition test in mice. Nat Protoc. 2013;8(12):2531-7. https://doi.org/10.1038/nprot.2013.155 Nature Publishing Group.
60. Antunes M, Biala G. The novel object recognition memory: neurobiology, test procedure, and its modifications. Cogn Process. 2012;13(2):93-110. https://doi.org/10.1007/s10339-011-0430-z Springer-Verlag.

61. Tremblay C, Francois A, Delay C, Freland L, Vandal M, Bennett, et al. Association of neuropathological markers in the parietal cortex with antemortem cognitive function in persons with mild cognitive impairment and Alzheimer disease. J Neuropathol Exp Neurol. 2017; 76(2):70-88.

62. Bousquet M, Gue K, Emond V, Julien P, Kang JX, Cicchetti F, et al. Transgenic conversion of omega- 6 into omega-3 fatty acids in a mouse model of Parkinson's disease. J Lipid Res. 2011;52(2):263-71. https://doi.org/10.1194/jr. M011692.

63. Poher A-L, Veyrat-Durebex C, Altirriba J, Montet X, Colin DJ, Caillon A, et al. Ectopic UCP1 overexpression in white adipose tissue improves insulin sensitivity in Lou/C rats, a model of obesity resistance. Diabetes. 2015;64(11): 3700-12. https://doi.org/10.2337/db15-0210.

64. Xiao C, Goldgof M, Gavrilova O, Reitman ML. Anti-obesity and metabolic efficacy of the $\beta 3$-adrenergic agonist, CL316243, in mice at thermoneutrality compared to $22^{\circ} \mathrm{C}$. Obesity (Silver Spring). 2015;23:1450-9.

65. Nam M, Cooper MP. Role of energy metabolism in the brown fat gene program. Front Endocrinol (Lausanne). 2015;6:104 Frontiers.

66. Hebda-Bauer EK, Simmons TA, Sugg A, Ural E, Stewart JA, Beals JL, et al. 3XTg-AD mice exhibit an activated central stress axis during early-stage pathology. J Alzheimers Dis. 2013;33:407-22 IOS Press.

67. Selkoe DJ, Hardy J. The amyloid hypothesis of Alzheimer' disease at 25 years. EMBO Mol Med. 2016;8(6):595-608. https://doi.org/10.15252/emmm.2 01606210 EMBO Press.

68. Iqbal K, Liu F, Gong C-X. Tau and neurodegenerative disease: the story so far. Nat Rev Neurol. 2016;12(1):15-27. https://doi.org/10.1038/nrneurol.201 5.225

69. Farris W, Mansourian S, Chang Y, Lindsley L, Eckman EA, Frosch MP, et al. Insulin-degrading enzyme regulates the levels of insulin, amyloid betaprotein, and the beta-amyloid precursor protein intracellular domain in vivo. Proc Natl Acad Sci U S A. 2003;100(7):4162-7. https://doi.org/10.1073/pnas. 0230450100 National Academy of Sciences.

70. Donahue JE, Flaherty SL, Johanson CE, Duncan JA, Silverberg GD, Miller MC, et al. RAGE, LRP-1, and amyloid-beta protein in Alzheimer's disease. Acta Neuropathol. 2006;112(4):405-15. https://doi.org/10.1007/s00401-006-0115-3 Springer-Verlag.

71. Arendt T. Synaptic degeneration in Alzheimer's disease. Acta Neuropathol. 2009;118(1):167-79. https://doi.org/10.1007/s00401-009-0536-x SpringerVerlag.

72. Calon F, Lim GP, Yang F, Morihara T, Teter B, Ubeda O, et al. Docosahexaenoic acid protects from dendritic pathology in an Alzheimer's disease mouse model. Neuron. 2004;43(5):633-45. https://doi.org/10.1016/j. neuron.2004.08.013.

73. Julien C, Tremblay C, Bendjelloul F, Phivilay A, Coulombe M-A, Emond V, et al. Decreased drebrin mRNA expression in Alzheimer disease: correlation with tau pathology. J Neurosci Res. 2008;86:2292-302 Wiley Subscription Services, Inc., A Wiley Company.

74. Kalaria RN, Harik SI. Reduced glucose transporter at the blood-brain barrier and in cerebral cortex in Alzheimer disease. J Neurochem. 1989;53(4):10838. https://doi.org/10.1111/j.1471-4159.1989.tb07399.x.

75. Simpson IA, Chundu KR, Davies-Hill T, Honer WG, Davies P. Decreased concentrations of GLUT1 and GLUT3 glucose transporters in the brains of patients with Alzheimer's disease. Ann Neurol. 1994;35:546-51 Wiley Subscription Services, Inc., A Wiley Company.

76. Liu Y, Liu F, lqbal K, Grundke-lqbal I, Gong C-X. Decreased glucose transporters correlate to abnormal hyperphosphorylation of tau in Alzheimer disease. FEBS Lett. 2008;582(2):359-64. https://doi.org/10.1016/j. febslet.2007.12.035.

77. Nicholson RM, Kusne Y, Nowak LA, LaFerla FM, Reiman EM, Valla J. Regional cerebral glucose uptake in the 3xTG model of Alzheimer' disease highlights common regional vulnerability across AD mouse models. Brain Res. 2010; 1347:179-85. https://doi.org/10.1016/j.brainres.2010.05.084.

78. Do TM, Alata W, Dodacki A, Traversy M-T, Chacun H, Pradier L, et al. Altered cerebral vascular volumes and solute transport at the blood-brain barriers of two transgenic mouse models of Alzheimer' disease. Neuropharmacology. 2014;81:311-7. https://doi.org/10.1016/j.neuropharm.2014.02.010.

79. Do TM, Dodacki A, Alata W, Calon F, Nicolic S, Scherrmann J-M, et al. Agedependent regulation of the blood-brain barrier influx/efflux equilibrium of 
amyloid- $\beta$ peptide in a mouse model of Alzheimer's disease (3xTg-AD). J Alzheimers Dis. 2016;49:287-300 IOS Press.

80. Bourasset F, Ouellet M, Tremblay C, Julien C, Do TM, Oddo S, et al. Reduction of the cerebrovascular volume in a transgenic mouse model of Alzheimer's disease. Neuropharmacology. 2009;56(4):808-13. https://doi. org/10.1016/j.neuropharm.2009.01.006.

81. Loh RKC, Formosa MF, La Gerche A, Reutens AT, Kingwell BA, Carey AL. Acute metabolic and cardiovascular effects of mirabegron in healthy individuals. Diabetes Obes Metab. 2019;21(2):276-84. https://doi.org/1 $0.1111 /$ dom. 13516 .

82. Nedergaard J, Cannon B. UCP1 mRNA does not produce heat. Biochim Biophys Acta. 2013;1831:943-9.

83. Harms M, Seale P. Brown and beige fat: development, function and therapeutic potential. Nat Med. 2013;19(10):1252-63. https://doi.org/10.103 8/nm.3361.

84. Adebakin A, Bradley J, Gümüsgöz S, Waters EJ, Lawrence CB. Impaired satiation and increased feeding behaviour in the triple-transgenic Alzheimer's disease mouse model. PLoS One. 2012;7:e45179 Gaetani S, editor. Public Library of Science.

85. Do K, Laing BT, Landry T, Bunner W, Mersaud N, Matsubara T, et al. The effects of exercise on hypothalamic neurodegeneration of Alzheimer's disease mouse model. PLoS One. 2018;13:e0190205 Lopez-Lluch G, editor. Public Library of Science.

86. Gavrilova O, Marcus-Samuels B, Reitman ML. Lack of responses to a beta3adrenergic agonist in lipoatrophic A-ZIP/F-1 mice. Diabetes. 2000;49(11): 1910-6. https://doi.org/10.2337/diabetes.49.11.1910.

87. Szentirmai É, Kapás $L$. The role of the brown adipose tissue in $\beta 3$-adrenergic receptor activation-induced sleep, metabolic and feeding responses. Sci Rep. 2017;7:958 Nature Publishing Group.

88. Griebling TL, Campbell NL, Mangel J, Staskin D, Herschorn S, Elsouda D, et al. Effect of mirabegron on cognitive function in elderly patients with overactive bladder: MoCA results from a phase 4 randomized, placebocontrolled study (PILLAR). BMC Geriatr. 2020;20(1):109. https://doi.org/10.11 86/s12877-020-1474-7.

89. Gibbs ME, Maksel D, Gibbs Z, Hou X, Summers RJ, Small DH. Memory loss caused by beta-amyloid protein is rescued by a beta(3)-adrenoceptor agonist. Neurobiol Aging. 2010;31(4):614-24. https://doi.org/10.1016/j. neurobiolaging.2008.05.018 Elsevier.

90. Gunstad J, Lhotsky A, Wendell CR, Ferrucci L, Zonderman AB. Longitudinal examination of obesity and cognitive function: results from the Baltimore longitudinal study of aging. Neuroepidemiology. 2010;34(4):222-9. https:// doi.org/10.1159/000297742 Karger Publishers.

91. Takeda S, Sato N, Uchio-Yamada K, Sawada K, Kunieda T, Takeuchi D, et al. Diabetes-accelerated memory dysfunction via cerebrovascular inflammation and Abeta deposition in an Alzheimer mouse model with diabetes. Proc Natl Acad Sci U S A. 2010;107(15):7036-41. https://doi.org/10.1073/pnas.1 000645107.

92. Abbondante S, Baglietto-Vargas D, Rodriguez-Ortiz CJ, Estrada-Hernandez T, Medeiros R, LaFerla FM. Genetic ablation of tau mitigates cognitive impairment induced by type 1 diabetes. Am J Pathol. 2014;184(3):819-26. https://doi.org/10.1016/j.ajpath.2013.11.021.

93. Rajasekar N, Nath C, Hanif K, Shukla R. Intranasal insulin improves cerebral blood flow, Nrf-2 expression and BDNF in STZ (ICV)-induced memory impaired rats. Life Sci. 2017;173:1-10. https://doi.org/10.1016/j.Ifs.2016.09.020.

94. Tong $X-K$, Trigiani $L J$, Hamel E. High cholesterol triggers white matter alterations and cognitive deficits in a mouse model of cerebrovascular disease: benefits of simvastatin. Cell Death Dis. 2019;10(2):89. https://doi. org/10.1038/s41419-018-1199-0

95. Evans BA, Papaioannou M, Bonazzi VR, Summers RJ. Expression of beta 3adrenoceptor mRNA in rat tissues. Br J Pharmacol. 1996;117:210-6.

96. Summers RJ, Papaioannou M, Harris S, Evans BA. Expression of beta 3adrenoceptor mRNA in rat brain. Br J Pharmacol. 1995;116:2547-8.

97. Stemmelin J, Cohen C, Terranova J-P, Lopez-Grancha M, Pichat P, Bergis $\mathrm{O}$, et al. Stimulation of the beta3-Adrenoceptor as a novel treatment strategy for anxiety and depressive disorders. Neuropsychopharmacology. 2008;33(3):574-87. https://doi.org/10.1038/sj. npp.1301424 Nature Publishing Group.

98. Consoli D, Leggio GM, Mazzola C, Micale V, Drago F. Behavioral effects of the beta3 adrenoceptor agonist SR58611 A: is it the putative prototype of a new class of antidepressant/anxiolytic drugs? Eur J Pharmacol. 2007:573(13):139-47. https://doi.org/10.1016/j.ejphar.2007.06.048.
99. Tamburella A, Micale V, Leggio GM, Drago F. The beta3 adrenoceptor agonist, amibegron (SR58611A) counteracts stress-induced behavioral and neurochemical changes. Eur Neuropsychopharmacol. 2010;20(10):704-13. https://doi.org/10.1016/.euroneuro.2010.04.006.

100. Schneider LS, Sano M. Current Alzheimer' disease clinical trials: methods and placebo outcomes. Alzheimers Dement. 2009;5(5):388-97. https://doi.org/1 0.1016/j.jalz.2009.07.038.

101. O'Connor A, Pannee J, Poole T, Arber C, Portelius E, Swift IJ, et al. Plasma amyloid- $\beta$ ratios in autosomal dominant Alzheimer' disease: the influence of genotype. Brain. 2021. https://doi.org/10.1093/brain/awab166.

102. Sproul AA, Jacob S, Pre D, Kim SH, Nestor MW, Navarro-Sobrino M, et al. Characterization and molecular profiling of PSEN1 familial Alzheimer' disease iPSC-derived neural progenitors. PLoS One. 2014;9(1):e84547. https:// doi.org/10.1371/journal.pone.0084547.

103. Kumar-Singh S, Theuns J, Van Broeck B, Pirici D, Vennekens K, Corsmit $E$, et al. Mean age-of-onset of familial Alzheimer disease caused by presenilin mutations correlates with both increased Abeta42 and decreased Abeta40. Hum Mutat. 2006;27(7):686-95. https://doi.org/10.1 002/humu.20336.

104. Tanzi RE. The genetics of Alzheimer disease. Cold Spring Harb Perspect Med. 2012;2:a006296 Cold Spring Harbor Laboratory Press.

105. Jacobsen JS, Wu C-C, Redwine JM, Comery TA, Arias R, Bowlby M, et al. Early-onset behavioral and synaptic deficits in a mouse model of Alzheimer's disease. Proc Natl Acad Sci U S A. 2006;103(13):5161-6. https:// doi.org/10.1073/pnas.0600948103 National Academy of Sciences.

106. Arber C, Toombs J, Lovejoy C, Ryan NS, Paterson RW, Willumsen N, et al. Familial Alzheimer' disease patient-derived neurons reveal distinct mutationspecific effects on amyloid beta. Mol Psychiatry. 2019;8:595.

107. Toombs J, Foiani MS, Wellington H, Paterson RW, Arber C, Heslegrave A, et al. Amyloid $\beta$ peptides are differentially vulnerable to preanalytical surface exposure, an effect incompletely mitigated by the use of ratios. Alzheimers Dement (Amst). 2018;10:311-21.

108. Oblak AL, Forner S, Territo PR, Sasner M, Carter GW, Howell GR, et al. Model organism development and evaluation for late-onset Alzheimer's disease: MODEL-AD. Alzheimers Dement Transl Res Clin Interv. 2020;6:e12110.

109. Finlin BS, Memetimin H, Zhu B, Confides AL, Vekaria HJ, el Khouli RH, et al. The $\beta 3$-adrenergic receptor agonist mirabegron improves glucose homeostasis in obese humans. J Clin Invest. 2020;130(5):2319-31. https:// doi.org/10.1172/JCl134892.

110. Hainer V. Beta3-adrenoreceptor agonist mirabegron - a potential antiobesity drug? Expert Opin Pharmacother. 2016;17(16):2125-7. https:// doi.org/10.1080/14656566.2016.1233177 Taylor \& Francis.

111. Weyer C, Tataranni PA, Snitker S, Danforth E, Ravussin E. Increase in insulin action and fat oxidation after treatment with $\mathrm{CL} 316,243$, a highly selective beta3-adrenoceptor agonist in humans. Diabetes. 1998;47(10):1555-61. https://doi.org/10.2337/diabetes.47.10.1555.

112. Chapple CR, Kaplan SA, Mitcheson D, Blauwet MB, Huang M, Siddiqui E, et al. Mirabegron $50 \mathrm{mg}$ once-daily for the treatment of symptoms of overactive bladder: an overview of efficacy and tolerability over 12 weeks and 1 year. Int J Urol. 2014;21:960-7 John Wiley \& Sons, Ltd (10.1111).

113. Chapple CR, Siddiqui E. Mirabegron for the treatment of overactive bladder: a review of efficacy, safety and tolerability with a focus on male, elderly and antimuscarinic poor-responder populations, and patients with $O A B$ in Asia. Expert Rev Clin Pharmacol. 2017;10(2):131-51. https://doi.org/10.1080/1 7512433.2017.1275570

114. Herschorn S, Staskin D, Schermer CR, Kristy RM, Wagg A. Safety and tolerability results from the PILLAR study: a phase iv, double-blind, randomized, placebo-controlled study of Mirabegron in patients $\geq 65$ years with overactive bladder-wet. Drugs Aging. 2020;37(9):665-76. https://doi. org/10.1007/s40266-020-00783-w.

\section{Publisher's Note}

Springer Nature remains neutral with regard to jurisdictional claims in published maps and institutional affiliations. 